\title{
New Reform Strategies and Welfare Participation in Canada
}

\author{
Nathan Berg and Todd Gabel
}

Address for correspondence:

Nathan Berg

Department of Economics

University of Otago

PO Box 56

Dunedin

NEW ZEALAND

Email: nathan.berg@otago.ac.nz

Telephone: 6434798648 


\title{
New Reform Strategies and Welfare Participation in Canada
}

\author{
Nathan Berg* and Todd Gabel**
}

\begin{abstract}
This paper measures the extent to which declines in Canadian welfare participation were associated with novel and aggressive welfare reforms. Referred to as new reform strategies, these welfare policy variables are: work requirements, diversion, earning exemptions, and time limits. Controlling for province-specific benefit levels, eligibility requirements, GDP growth, labor market conditions and demographics, the data suggest that welfare participation rates were more than one percentage point lower (equivalent to at least a 13\% decline in welfare participation) in provinces where new reforms were present. Work requirements with strong sanctions for non-compliance had the sharpest negative associations with participation rates. Adoption of new reform strategies explains at least 10 percent of observed declines in welfare participation from 1994 to 2009, roughly twice as much as cuts to benefit levels and stricter eligibility requirements can explain.
\end{abstract}

Keywords: Social Assistance, PRWORA, TANF, Work Requirements, Diversion, Earnings Exemptions, Time Limits, Natural Experiments

JEL Codes: H53, I38

*Nathan Berg, nathan.berg@otago.ac.nz, Associate Professor of Economics, University of Otago, New Zealand.

**Todd Gabel, tgabel@yahoo.com, Assistant Professor of Economics, Middle Tennessee State University.

The authors would like to thank Rodney Andrews, Sheldon Danziger, Chetan Dave, Jim Murdoch, Ahmed Saleh Alzahrani, Diane Richard at the National Council of Welfare, and Jim Vajionis at Statistics Canada. 


\section{NEW REFORM STRATEGIES AND WELFARE PARTICIPATION IN CANADA}

\section{INTRODUCTION}

During the 1990s and 2000s, Canada's welfare system ${ }^{1}$ transitioned from a relatively centralized program with federal administrative controls to a decentralized mix of programs in which provinces had considerable discretion to undertake new policies. This transition led to substantially different welfare programs across provinces and years, reflecting heterogeneity in the composition and timing of provinces' attempts at reducing the number of welfare recipients. Passage in 1996 of The Canada Health and Social Transfer (CHST) implemented block-grant funding and removed most federal rules concerning how provinces managed their welfare systems. Changes in provinces' welfare programs that followed did not occur at the same times, however, and were far from uniform in content and stringency of implementation. ${ }^{2}$ Some provincial governments experimented aggressively with new policy tools aimed at reducing welfare participation. Others did not. In different years and by different amounts, nearly all provinces reduced welfare benefit levels and tightened eligibility requirements. The phrase

\footnotetext{
${ }^{1}$ Welfare refers to government programs that provide cash benefits to individuals with low incomes. In Canada, welfare is referred to as social assistance.

${ }^{2}$ A key aspect of CHST that distinguishes the extent of decentralization in Canada from that of the U.S. is the absence of new federal mandates in Canada's CHST. In contrast, the U.S.'s Personal Responsibility and Work Opportunity Reconciliation Act (PRWORA) required a specific set of new policies for all states: five-year time limits on welfare participation and work requirements for a minimum proportion of each state's welfare clients. Federal law also partially restricted US states from lowering benefit levels. Decentralization of Canada's welfare system had no federal mandates aimed explicitly at reducing welfare participation or incentivizing work. While US states were given discretion in other policy areas such as earnings exemptions and diversion strategies, federally mandated work requirements led to relatively similar sets of policy changes going into effect across the 50 states shortly after passage of PRWORA in 1996. Federal limits on cuts in benefit levels in the U.S., once again, led to more uniformity among states than was the case among provinces. These two layers of federal control guiding welfare reform in the U.S. (and not part of Canada's decentralized reforms) suggest at least the possibility that the most stringent among provinces' new welfare reforms could have exceeded, in stringency, those that took place in most states. For example, British Columbia adopted reforms comparable to PRWORA and cut benefit levels. In general, Canada's welfare reforms were, by nearly all accounts, less stringent than the U.S.'s. Heterogeneity across provinces and time is the main point of contrast with the U.S., however, as decentralization in Canada reduced federal control over province-level welfare policy to a greater extent than in the U.S., stringency notwithstanding. This heterogeneity, in turn, generated substantial variation in provinces' welfare system policy variables, which this paper attempts to code in greater detail than in previous econometric studies of welfare participation.
} 
standard tools is introduced to distinguish benefit levels and eligibility requirements (which have been studied extensively in multiple literatures spanning several major subfields of economics) from the policy tools that are the focus of this paper: work requirements, diversion, earnings exemptions, and time limits (described in more detail in subsequent sections), which are jointly referred to as new reform strategies. Heterogeneous adoption decisions, adoption dates and stringency of enforcement regarding these new reform strategies overlapped in different ways with benefit reductions and tightening of eligibility requirements, potentially obscuring their effects on welfare participation.

In 1994, Canada's welfare participation rate reached a high of $12.5 \%$ of the non-elderly adult population and thereafter began to decline two years prior to passage of the CHST. Following passage of the CHST, welfare participation continued to decline and remained substantially lower. This imperfectly overlapping timing raises questions as to what role, if any, did new reform strategies undertaken by provinces play in observed declines in welfare participation.

This paper attempts to address this question by measuring disaggregated effects of new reform strategies on provinces' welfare participation rates, while controlling for changes in benefit levels, eligibility requirements, labor market conditions, GDP growth and demographic composition. All variables, including GDP growth and labor market conditions, are provinceand year-specific. Heterogeneity of provinces' adoption decisions and adoption dates can be considered as multiple natural experiments. These natural experiments provide valuable statistical information with which to measure the effects of new reform strategies even though benefit levels and eligibility requirements were changing over the same years. 
A substantial literature documents the important effects of benefit levels and eligibility requirements on welfare participation. Allen (1993) uses micro-data to show that differences in benefit levels and asset exemption levels among provinces have statistically and economically significant effects matching the predictions of theory. Dooley's (1999) longitudinal micro-data study of single mothers similarly finds that benefit levels relative to wages (while controlling for age and family structure) explain a large share of variation in welfare participation decisions among this important subpopulation. Christofides, Stengos and Swidinsky (1997) and Christofides (2000), however, argue that changes in wages and personal characteristics may be more important than changes in benefit levels and other institutional variables used to characterize welfare programs. Klassen and Buchanan (1997) focus on eligibility requirements and find that labor market conditions influence welfare participation rates more powerfully than eligibility requirements do. ${ }^{3}$

Compared to the substantial literature focused on benefit levels and eligibility requirements, few studies have attempted to measure the effects of work requirements, diversion, earnings exemptions, and time limits (i.e., new reform strategies) as implemented in Canada and compare their effect size to that of benefit levels and eligibility requirements. The heterogeneity of provinces' new reform strategies that makes these policy variables potentially rich with statistical information also presents a formidable challenge. This paper attempts to address the challenge of coding heterogeneous welfare program rules, enforcement practices and their timing into variables that can be operationalized within an otherwise standard econometric model. Finnie and Irvine (2008) provide a useful discussion of the potentially important role that new reform strategies might have played in influencing welfare participation rates. Using micro-data

\footnotetext{
${ }^{3}$ Blank (2001, 2002), Acs, Phillips and Nelsen (2005), and Ribar (2005) investigate the determinants of US welfare participation focusing on new reform strategies described in this paper while controlling for benefit levels.
} 
to study the effects of unemployment benefits and social assistance benefits on welfare entry and exit, Finnie and Irvine's (2008) econometric strategy attempts to capture potentially confounding unobserved variation in new reform strategies by using year fixed effects. The intent of this paper is to complement their approach by utilizing additional sources of information about provinces' adoption decisions, timing, and stringency of enforcement concerning the four new reform policy variables.

Using a more aggregated policy measure than ours, Kneebone and White's (2009) model addresses an important aspect of what this paper is trying to measure (i.e., the effect of new reform strategies relative to the standard policy tools of benefit levels and eligibility requirements). Kneebone and White introduce a variable referred to as Administrative Procedures, which is an indicator that "turns on" from 0 to 1 for province-years in which strong administrative procedures for reducing welfare participation were in effect: Alberta (1993-2003), British Columbia (1996-2003) and Ontario (1996-2003). ${ }^{4}$ We undertake to implement a more disaggregated coding methodology that maps a substantial body of source material (published by provincial governments and third-party analyses of stringency of enforcement in different province-years) into policy variables measuring the presence of new reform strategies. Coding this additional information enables our empirical models to more precisely quantify which among these policy mechanisms are most strongly associated with the observed declines in provinces' welfare participation rates.

\footnotetext{
${ }^{4}$ Shannon (2009) coded provinces into categories that distinguish aggressive versus non-aggressive reforms in the context of explaining labor supply decisions. See also Green and Warburton (2004), who examine the effects of diversion strategies in $\mathrm{BC}$ on long-run welfare participation.
} 
The empirical models presented below use data covering the 24-year period from 1986 to 2009 with the "province-year" as the unit of observation. ${ }^{5}$ This contrasts with Kneebone and White (2009), whose estimates use 15 years of data ranging from 1989 to 2003 . By incorporating the years 2004-2009, the estimates reported in this paper more fully reflect British Columbia's aggressive implementation of new reform strategies which began in 2002, as well as those adopted by Nova Scotia's and, to a lesser extent, Saskatchewan, in 2001.

Table 1 summarizes new reform strategies adopted in the provinces since 1986. Documents released by provincial welfare agencies and numerous other sources guided the taxonomy laid out in Table 1. The categories for classifying new reform strategies are: work requirements with strong sanctions for non-compliance, work requirements with weak sanctions, strong diversion (of those who seek to enter the welfare program by guiding them to alternative sources of support), weak diversion, earnings exemptions ${ }^{6}$ (aimed at encouraging work), and time limits (that cap the duration for which recipients can receive benefits). ${ }^{7}$ According to Table 1 , most provinces pursued some type of new reform strategy, although the stringency of sanctions used to enforce work requirements and diversion varied in important ways, as recorded

\footnotetext{
${ }^{5}$ At the time of writing, Canada's National Council of Welfare had published welfare participation counts broken out by province only through 2009. In 2012, the National Counsel of Welfare was defunded by the Canadian federal government and was no longer in operation.

${ }^{6}$ In the models introduced subsequently, three variables code variation in earning exemptions across province years: the earning exemption threshold, the tax back rate on earnings above this threshold, and an interaction term.

${ }^{7}$ Note that the adjective "new" is slightly misleading in the case of earnings exemptions, since some provinces experimented with them decades earlier. In the beginning year of our sample long before passage of The CHST, virtually all provinces had some form of earnings exemptions in place allowing welfare recipients to keep a non-zero fraction of labor market earnings. One reason for classifying earnings exemptions as "new reform strategies" is because some provinces used them more aggressively during 1986-2009. Another reason: prior to the U.S.'s passage of PRWORA in 1996 (see footnote 2), labor market earnings of long-term welfare participants in the U.S. were taxed at $100 \%$, generating a potentially strong disincentive to work. In the welfare participation literature analyzing reforms in the U.S., earnings exemptions are generally regarded as one of the important new reform strategies put forward by advocates of welfare reform.
} 
in the column headings that distinguish weak from strong versions of work requirements and diversion. $^{8}$

The paper proceeds as follows. Section 2 describes Canadian welfare participation rates at the national and provincial levels and documents differences in benefit levels and eligibility requirements, income growth and unemployment rates, and adoption of new reform strategies across provinces and years. These groups of variables - standard welfare reform tools, labor market policy tools, macroeconomic factors and new reform strategies -- serve as four competing categories of information to explain the observed reductions in welfare participation that took place from 1994 through 2009. Section 3 presents summary statistics and specifies the empirical models used to estimate the effects of these explanatory variables on welfare participation. Section 4 presents empirical results based on finely disaggregated new reform variables that code the information collected from ministerial sources summarized in Table 1. The robustness of the new information revealed by the disaggregated multi-dimensional representation is investigated by comparing those findings with alternate model specifications using a single (more coarsely measured) new reform variable and more general dynamic specifications. The findings in Section 4 are intended to address the question posed earlier of measuring the effects of new reform strategies and comparing effect size with other factors thought to influence welfare participation. Section 5 concludes with discussion and interpretations of the empirical findings.

\footnotetext{
${ }^{8}$ Source material and the method for coding Weak versus Strong are discussed in the following section. Appendix A presents additional detail.
} 


\section{DECLINING WELFARE PARTICIPATION AND CONCURRENT POLICY}

\section{CHANGE}

\section{Welfare Participation in Canadian Provinces}

Figure 1 shows welfare participation time paths for Alberta, British Columbia, Ontario, and an aggregate of other provinces (weighted by population). The time paths in Figure 1 vary considerably both in level and trend. ${ }^{9}$ Welfare participation peaks in all provinces between 1993 and 1997. Subsequent declines are nearly monotonic, although levels and rates of decline vary considerably. For example, Figure 1 shows a significant decline in welfare participation in British Columbia since 2002 not observed in other provinces. ${ }^{10}$

Table 2 computes changes in welfare participation rates in levels (i.e., in units of percentage points) and percentage declines by province from 1994 (the year in which Canada's national rate of welfare participation peaked at $12.5 \%$ ) to 2009 . Despite heterogeneity among provinces' welfare programs as seen in both Figure 1 and Table 1, every province experienced large declines in welfare participation since 1994, which leaves open the possibility that macroeconomic factors common across provinces were also responsible for a portion of the observed declines. Heterogeneity across provinces is clearly visible both in Figure 1 and Table 1, however. Alberta's welfare participation rate declined by more than $66 \%$ (the largest percentage change in Table 2) while Newfoundland's declined by less than $31 \%$. Ontario had the largest absolute decline in welfare participation rates, dropping by 7.8 percentage points.

\section{$\underline{\text { Standard Reform Tool \#1: Reductions in Welfare Benefits }}$}

\footnotetext{
${ }^{9}$ Based on data from the National Council of Welfare (2003, 2006, 2009), welfare participation rates are computed annually as the fraction in each province of the non-elderly population (those strictly under the age of 65) receiving welfare in March of a given year.

${ }^{10}$ In general, the rate of welfare participation is higher in Canada than in the U.S. In part, this is because adults with no children are eligible for benefits in Canada, while only adults with dependent children are eligible in the U.S.
} 
Each province has its own formula mapping household type (i.e., numbers of adults and children in the household) of welfare-eligible individuals into benefit levels for individuals in that household. ${ }^{11}$ Table 3 shows percentage declines in real welfare benefit levels (applying province-specific CPI deflators) for individuals classified in the three most common household types. Benefit levels fell in nearly all provinces across most household types. ${ }^{12}$ In general, provinces aggressively reduced welfare benefit levels after 1994 although this trend has slowed or reversed since 2005. Some provinces such as British Columbia reduced benefits similarly across different household types. Others such as Manitoba, New Brunswick and Prince Edward Island cut benefits more sharply for childless welfare participants (listed in Table 3 under the column labeled Single, No Child). ${ }^{13}$ In a number of instances, however, real benefits rose (which sometimes coincided with more stringent eligibility requirements and combinations of new reforms). Newfoundland, for example, raised real benefits for individuals in Single, No Child households by a remarkable $59 \%$.

\section{$\underline{\text { Standard Reform Tool \#2: Tightening Eligibility Requirements }}$}

Eligibility requirements include means tests, asset exemption limits, age restrictions on teenage participation, and residency requirements. ${ }^{14}$ Unfortunately, there are insufficient data to

\footnotetext{
${ }^{11}$ Welfare participants are individuals rather than households. A household can have multiple members participating on welfare who are counted individually as welfare participants. Formulas used by provinces to compute individual benefit levels depend, however, on the individual's household type.

${ }^{12}$ These trends in Canada contrast with those in the U.S., where states were more constrained in their ability to reduce benefit levels.

${ }^{13}$ Classifying household types is not always straightforward, especially the designations single and coupled. Following the National Council of Welfare's interpretation of these terms, single refers to an adult living at an address with no other adults living at the same address. By this definition, the label single provides no definitive information about relationship or marital status. One presumes that single correlates with being unmarried and, perhaps more weakly, with having no partner to provide financial support and assist in raising children. Similarly, the designation coupled refers to an adult living at an address with precisely one other adult.

${ }^{14}$ One of the most well known shifts in eligibility requirements occurred in 1987, when Ontario passed the "spouse in the house" rule that expanded eligibility for welfare by enabling unmarried, cohabitating couples to qualify for welfare as single adults for up to three years. Ontario's policy was unique among provinces and led to an estimated increase of 9,000 single parents who were made newly eligible for welfare (Holden, 1987), providing one example of the potential importance of changes in eligibility requirements (in both directions).
} 
individually code all these criteria used by provinces in each province-years. Although not ideal, our coding approach relies on the maximum liquid asset exemption level for each province-year. Applicants with liquid assets in excess of this dollar amount are not eligible for welfare.

Compared with benefit levels, there is far less year-over-year change in asset exemption levels within provinces, although changes tend to be rather large when they do occur. ${ }^{15}$

\section{$\underline{\text { Labor Market Policy Tools }}$}

In addition to benefit levels and eligibility requirements, government also controls minimum wage and Employment Insurance (EI), which are primary incentives affecting labor supply. Prior to 1990, an individual in Canada could work 10 weeks and qualify for 42 weeks of employment insurance benefits. The federal government reformed EI policy during the 1990s to discourage overuse. Following Arnau, Cremieux and Fortin (2005) and Finnie and Irvine (2008), we use three policy parameters - the minimum number of weeks of work required to gain eligibility for EI, the duration of EI benefits for someone who is minimally qualified for the program, and the income replacement rate - to construct an EI index as a measure of the wage subsidy provided by the EI program. ${ }^{16}$ The impact of this wage subsidy on welfare participation is theoretically ambiguous. To the degree that EI and welfare are substitutes, theory predicts that larger EI wage subsides would reduce welfare participation. If they are complements, however, one expects that larger EI wage subsidies would induce entry into income support programs and therefore increase welfare participation.

\section{$\underline{\text { New Reform Strategies }}$}

Despite variation in benefit levels and eligibility requirements, some observers have argued that experimentation with new welfare reform strategies exerted even stronger influence

\footnotetext{
${ }^{15}$ For example, British Columbia in 1992 raised asset exemption limits from $\mathrm{C} \$ 1500$ to $\mathrm{C} \$ 5000$ (in nominal terms) after leaving them unchanged for six years prior, but later reduced the exemption limit to C\$2500 in 2002.

${ }^{16}$ EI's policy parameters are set federally using formulas that depend on a province's unemployment rate.
} 
on welfare participation in Canada (NCW, 1997; Gorlick and Brethour, 1998). According to

Table 1, there were four broad categories of new reform strategies described below.

Work Requirements. Work requirements refer to policies that require welfare participants to search for work, participate in job training programs, volunteer, or hold a job in the private or public sector. Typically, welfare participants are required to regularly document job search, training, and work activities to continue receiving benefits. Depending on the province-year, failure to comply with these work requirements could result in sanctions (i.e., penalties, usually in the form of reduced welfare payments). Provinces' policies differed in whether and how much welfare participants would lose for failing to comply with work requirements. The coding scheme adopted here classifies work requirements as Weak if sanctions for non-compliance require forfeiting more than zero and less than $100 \%$ of the monthly benefit payment. ${ }^{17}$ Work requirements are considered Strong if welfare participants face losing $100 \%$ of the welfare benefit as a sanction for non-compliance. ${ }^{18}$

In the labor supply model presented by Grogger and Karoly (2005, p.49), work requirements are modeled in leisure-income space as a change in the budget set that forces welfare recipients to forfeit a fixed quantity of leisure to receive the welfare benefit. According to this theory, it is assumed that the effective tax rate on labor market earnings while on welfare is less than $100 \%$ so that the required reduction in leisure can be traded for some positive financial gain. The resulting prediction is that work requirements increase employment in one of two ways. The required reduction in leisure may induce a welfare recipient to choose a new

\footnotetext{
${ }_{17}^{17}$ Sanctions in province-years with Weak work requirements typically amount to $\$ 100$ or less per month.

${ }^{18}$ This classification scheme follows convention frequently used in studies with US data (e.g., Danielson and Klerman, 2008). Since Newfoundland and Quebec (with the exception of the years 1990 through 1994) had work requirements with no sanctions to punish non-compliance, they are coded as having no work requirement at all. As part of this classification, stringency of enforcement was considered as well - for example, how easy it is for recipients facing sanctions to appeal, and whether welfare case workers have discretion not to impose sanctions.
} 
corner solution with positive labor supply while remaining in the welfare program. Or, if the reduction in leisure is large enough, the theory predicts that work requirements lead to an increase in labor supply together with an exit from welfare participation, either at a leisureincome pair on the interior of the budget set or at another corner solution where the required forfeit of leisure is tradable at market rates for an income level that exceeds the welfare benefit.

In search-theoretic models of labor supply, two distinct costs of remaining on welfare can be identified with depreciation of human capital based on the theory that some forms of human capital require that it be put to use to avoid higher rates of depreciation. If work requirements slow the depreciation of human capital (or perhaps even cause it to grow), then, all else equal, work requirements would increase the chance of finding work and raise the expected wage conditional on finding work. These effects increase the opportunity cost of remaining on welfare. Both static and dynamic search models imply that work requirements should lead to increases in employment and reductions in welfare participation insofar as they raise the opportunity cost of remaining on welfare. The extent to which work requirements reduce welfare participation depends on how costly the unpaid work-related activities are in terms of forgone leisure and the severity of sanctions for non-compliance in terms of lost benefits (i.e., the marginal cost of leisure jumping higher as the threshold into non-compliance triggers sanctions).

Diversion. Diversion refers to policies that offer people trying to enter the welfare program a negotiated lump-sum payment and/or guidance to seek other sources of support instead of directly entering the program and beginning to draw recurring benefits. Even if diversion incurs up-front costs for the welfare program, it can (at least in theory) save the welfare program money over the long term by slowing entry and reducing rates of long-term welfare participation. Diversion is classified as Weak if the policy functions primarily as an information 
campaign that notifies would-be welfare applicants of work opportunities, their eligibility for other government programs (e.g., unemployment insurance), and spousal or family support (especially alimony and child support payments). Diversion is classified as Strong if case workers who screen welfare applicants have discretion to do one of the following: offer immediate cash loans or one-time payments (e.g., to cover short-term job- or search-related costs); institute waiting periods that automatically delay eligibility for would-be applicants; or require would-be applicants to liquidate all assets, move in with relatives, visit food banks, or satisfy other prerequisites before applications for recurring welfare benefits are considered. For example, since 2002, British Columbia has required applicants to document job search during a mandatory three-week waiting period before proceeding with an application and receiving the first welfare payment. Diversion is predicted to reduce welfare participation based on the theory that temporarily avoiding entry into the program and increasing the hassle costs of completing entry will induce some to decide against entry. The diversion strategy typically requires applicants to complete lengthy questionnaires and provide additional documentation, raising the cost of applying. Dynamic models where the probability of employment decreases as a function of time spent in the program further predict that diversion shortens spells on welfare and thereby reduces participation.

Earning Exemptions. Historically, welfare participants face very high effective marginal tax rates, because income from employment typically triggers loss of means-tested welfare benefits (Anderson, 1978; Wolfe, 2002; and Grogger and Karoly, 2005). Earning exemptions function as tax cuts on the labor market earnings of welfare recipients, aiming to encourage work by exempting some portion of labor market earnings from taxes. Coding focuses on two parameters that characterize a province's earnings exemption policy. First, there is a threshold 
up to which point earnings are not taxed at all, typically in the range of C\$100 to C\$300 per month. The second parameter is the marginal tax rate applied to labor market earnings above this threshold. Table 1 classifies province-years as having earnings exemptions if: (1) the threshold of allowable tax-free earnings is strictly greater than zero, and (2) the marginal tax rate for earnings above this threshold is strictly less than $100 \%{ }^{19}$

Time Limits. Time limits refer to policies that set a maximum duration for which welfare benefits can be received. British Columbia is the only province to ever institute time limits. British Columbia's time limits allow welfare participants to receive benefits for a maximum of two years out of every five-year period. Although less stringent than US time limits that set lifetime limits on the duration of welfare participation ${ }^{20}$, theory predicts that time limits, if credible, raise the opportunity cost of participation by reducing the expected value of future streams of welfare benefits. By raising the cost of remaining on welfare, time limits are predicted to reduce participation by causing potential and current welfare participants, on the margin, to ration their use of the welfare system so as to maintain eligibility for future participation (Grogger and Karoly, 2005, p. 49).

\section{DATA SUMMARY AND MODELS OF WELFARE PARTICIPATION}

\section{$\underline{\text { Data Sources }}$}

Data from 1986 to 2009 on welfare participation, welfare benefit levels, as well as earnings and asset exemptions were obtained from the National Council of Welfare (1987) and its Welfare Incomes series published most years from 1990 through 2009. The National Council

\footnotetext{
${ }^{19}$ Models reported below include these two earnings exemptions variables and an interaction term.

${ }^{20}$ In the U.S., time limits were first introduced under PRWORA. This federal law imposes a five-year lifetime limit. Some states have enacted lifetime limits as low as two years. Large numbers of participants in both the U.S. and British Columbia qualify for exemptions from time limits, which adds to the difficulty of quantifying the extent to which time limits in either country succeed in raising the opportunity cost of welfare participation.
} 
of Welfare never published welfare participation numbers for 1987 and 1988. The empirical results reported in this paper rely on interpolated participation numbers for those two years.

One potentially important limitation of the participation data is their aggregation of disabled and non-disabled recipients of social assistance. Disabled participants faced distinct labor market incentives in making labor supply decisions. Provinces' criteria for determining who is disabled shifted substantially. And, in many cases, welfare policies directed at nondisabled participants did not affect disabled participants in the same ways. Therefore, it would be useful in measuring the effects of changes in welfare policy to have separate counts for disabled and non-disabled welfare participants. We searched for, but were unable to locate, usable data with counts or proportions of welfare participants broken out by disabled status across all province-years. Disability status and benefit levels for the disabled changed heterogeneously across provinces. As part of welfare reform, most provinces applied narrower criteria for determining disability status while maintaining benefit levels for those who still qualified (or cutting them by substantially less). At the same time, some provinces appeared to shift formerly non-disabled welfare participants with longer welfare spells into disability programs. $^{21}$

Another data limitation concerns household types among welfare participants. Ideally, one would want to include information that disaggregates participation according to the four household types in the National Council of Welfare's classification of benefit levels. Although one can find this information in a micro-panel sample (Survey of Labour Income Dynamics) housed at Statistics Canada, we were unable to find aggregate participation data broken out by household type. The result is that the controls for changes in benefit levels are not measured as

\footnotetext{
${ }^{21}$ For instance, since the adoption of Ontario Works in 1996, the amount of disabled cases in Ontario rose even though the province's other caseloads were falling.
} 
precisely as would have been possible with aggregate participation data broken out by household type. The empirical models of participation therefore apply to aggregate province-year participation rates and include all welfare participants (i.e., aggregating over individuals regardless of disability status and household type).

Welfare benefit levels are expressed in C $\$ 2009$ using province-specific CPI deflators. Benefit levels include basic assistance, provincial tax credits, provincial child benefits, the GST credit, and the Federal Child Tax Benefit. Some provinces chose to "claw back" a portion of the Federal Child Tax Benefit by reducing basic benefit levels. We use the benefit levels for a single parent with one child to approximate the relative generosity of the welfare program in each province. ${ }^{22}$ Province-specific population counts, demographic information, unemployment rates, real GDP growth, and market income (median of the second income quintile) were collected from data files compiled by Statistics Canada. ${ }^{23}$ Employment insurance eligibility criteria were obtained from the Employment Insurance Act (S.C. 1996, c. 23), Beauchesne (1994) and Waddell (1989). ${ }^{24}$ $\underline{\text { Summary Statistics }}$

\footnotetext{
${ }^{22}$ The models in this paper use benefit levels for individuals whose household type is Single Parent, One Child. As the changes in benefit levels were non-uniform across household types as shown in Table 3, any scalar-valued proxy is necessarily imperfect. According to Human Resources and Skills Development Canada (HRSDC, 2006), 61\% of all adult welfare recipients in 2005 (excluding the disabled) had Single, No Child household status, while another $21 \%$ were single with at least one child. Alternate runs of all models reported in this paper using a weighted average index of benefit levels did not overturn the reported findings on the effects of new reform strategies. Two points argue in favor of using Single, One Child as a proxy for benefits. First, the anomalous $45 \%$ increase in benefits for childless welfare recipients makes Newfoundland a troublingly influential outlier. The second point is that single parent households tend to have longer spells on welfare (Barrett and Cragg, 1998) and therefore substantially larger per-case costs accounting for a larger share of all social assistance transfer payments.

${ }^{23}$ Statistics Canada data files used in our data sets are: Provincial Economic Accounts, Income Trends in Canada 1976 to 2009, CANSIM database tables 051-0012, 051-0020, 051-0012, 202-0701, 276-0001, 282-0086, 384 - 0009, and the Labour Force Survey (Statistics Canada, 2007, 2009, 2010a, 2010b).

${ }^{24}$ Canadian data sources use the term "employment insurance" instead of "unemployment insurance."
} 
Table 4 presents summary statistics for variables used in the empirical models. The number of observations is 240 province-years ( 10 provinces observed over 24 years). ${ }^{25}$ The dependent variable is welfare participation (PARTICIPATION), measured as the fraction of the non-elderly population (age 64 and under) in each province-year counted as welfare participants. $^{26}$ The empirical range of PARTICIPATION extends from the maximum of $14.67 \%$ (Newfoundland in 1997) to the minimum of $1.57 \%$ (Alberta in 2007).

Coding each new reform variable as a distinct dimension within a vector-valued description of a multi-dimensional welfare policy environment, the finely coded representation of new reform strategies consists of the following eight variables: WORKREQ_STRONG, WORKREQ_WEAK, DIVERSION_STRONG, DIVERSION_WEAK, and TIMELIMITS (indicator variables based on Table 1), plus earnings exemption variables and their interaction,

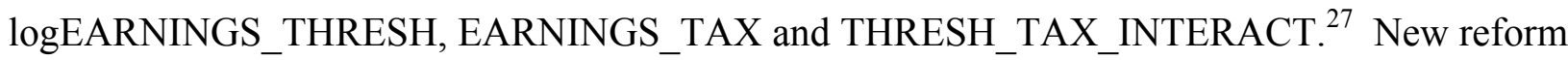
strategies coded as indicator variables that were adopted mid-year are represented by a fraction based on the number of months (out of 12) that those policies were in effect. ${ }^{28}$ A second set of

\footnotetext{
${ }^{25}$ Appendix A provides additional detail on source documents and coding new reform variables. Appendix V lists and describes all variables used in estimation.

${ }^{26}$ We also experimented with transformed versions of the dependent variable (e.g., natural log and re-scaled arc-tan transformations) mapping the unit interval to theoretically unbounded subsets of the real number line. These transformations led to greater asymmetry (i.e., skewness or non-normality) in the corresponding empirical distributions and increased the influence of observations in the tails of the distribution. Thus, untransformed welfare participation rates appeared to be the best option for the dependent variable in the empirical welfare participation models reported in the next section.

${ }^{27}$ Real maximum earnings thresholds (logEARNINGS_THRESH) were transformed by adding one dollar before taking natural logs.

${ }^{28}$ A potentially important issue concerns the coding of policies implemented in month $m \in\{2,3, \ldots, 12\}$ of year $t$ and possible sensitivity of regression estimates to whether these policies are coded as occurring in year $t$ versus $t+1$. Three approaches were investigated, which produced hardly any noticeable differences in estimated regression coefficients. The first approach was "aggressive time coding" indicating 1 in the year of implementation $(t)$ regardless of the month in which it began. The "intermediate time coding" approach assigned the value of 0 to the reform variables in years prior to $t$, a value of $(13-m) / 12$ in year $t$, and a value of 1 in all years thereafter for which the policy remained in effect. Policies that were discontinued received a fractional value that similarly depended on how many months out of 12 the policy remained in effect. Finally, the "conservative time coding" approach assigned 1 to each reform variable in year $t+1$ and 0 prior to that. Whether policies that were implemented or discontinued mid-year were considered to be in force retroactively from the beginning of the year, fractionally throughout the year, or only in effect at the start of the following year led to no substantial differences.
} 
empirical models is specified with a coarsely coded variable, NEWREFORM, which takes on the value of 1 in any year in which three or more of the new reform strategies were in effect.

According to Table 4, the mean of 0.22 for WORKREQ_STRONG indicates that $22 \%$ of the 240 province-years in the sample have strong work requirements in effect. Table 4 also shows that weak work requirements were more common in Canada, having been active in $25 \%$ of province-years. The mean value of EARNINGS_TAX of $82 \%$ in Table 4 shows the high marginal tax rates faced by welfare participants on earnings above the exemption threshold.

The question arises as to whether there is sufficient variation among province-years for the eight finely coded new reforms to be identified. Correlations between these eight variables are generally small. One exception, however, is WORKREQ_STRONG and DIVERSION_STRONG, which have pairwise correlation of 0.82 based on 13 years in which Alberta, British Columbia and Ontario had both in effect. WORKREQ_STRONG is present in 54 province-years (including three partial-year values), of which 17 also have zero or partial-year values for DIVERSION_STRONG, which identifies the difference. Despite substantial variation across province-years (in finely coded new reforms) visible in Table 1, concerns about weak statistical identification motivate coding of the scalar-valued variable NEWREFORM. According to Table 2, its mean of 0.28 indicates that $28 \%$ of province-years have three or more new reform strategies (weak or strong) in effect.

The unemployment rate for each province-year among prime-age males (ages 25-54), UNEMPLOYMENT, serves as a proxy for inverse tightness of labor market conditions. Using this subpopulation's unemployment rate is likely to be better calibrated to labor market conditions that welfare participants face and reduces co-linearity with the EI index, which uses each province-year's unemployment rate among all individuals in the labor force. The province- 
specific GDP growth rate, REALGDPGROWTH, is included as a further control for changes in province-specific labor demand. The empirical models include contemporaneous and lagged values (not listed separately in Table 4) of UNEMPLOYMENT and REALGDPGROWTH. The variable measuring benefit levels, logBENEFITS_SINGLE_ONECHILD, ranges from 9.50 to 10.03 , covering slightly more than 50 log-approximated percentage points as shown in Table 4. Eligibility requirements are measured as logASSET_THRESH (with higher asset thresholds indicating more lenient rules for welfare participation), which has a very large empirical range of variation of $2.77(=9.68-6.91)$ revealing substantial policy change in eligibility requirements both within and between provinces.

Controls for alternative income sources (earned income or benefits from programs other than welfare) include the natural log of median income among those in the second income quintile (logINCOME_2NDQUINTILE) and logEI_INDEX. Where applicable, all variables expressed in Canadian dollars are converted from nominal to real using province-specific CPI deflators and expressed in units of $\$ C 2009$. Since the market wage for low-skilled workers can be greater than the minimum wage, income levels in the 2 nd income quintile provide useful information that control for alternate sources of income among potential welfare participants, which follows the empirical model of Kneebone and White (2009). Alternative runs of our empirical models using the median of the first (lowest) quintile and, alternatively, minimum wage closely tracked results reported in the next section. The relative generosity of the EI program, which provides transfer payments to non-elderly out-of-work Canadians, was approximated by using the natural log of (one plus) the EI index as specified in Arnau, Cremieux and Fortin (2005) and Finnie and Irvine (2008). Finally, the empirical models include four controls for demographic differences across provinces and time. The proportion of single parents 
in the 64-and-under population is measured by SINGLEPARENTS (on a 0-100 scale), which provides a control for differences in demand for welfare. The inter-province rate of migration (i.e., the net number of people moving into a province as a fraction of the destination province's non-elderly population) is measured by the variable MIGRATION. Differences in the lower tail of the distribution of education outcomes are measured by DROPOUT, which records each province-year's high school dropout rate. This variable controls for another mechanism that influences demand for welfare, based on theory and observation which imply that provinces with higher stocks of formal education and more skilled workers are likely to have lower demand for income support programs (Coelli, Green and Warburton, 2007). Non-permanent residents as a share of the non-elderly population in each province-year is measured by NONPERM_RESIDENTS, which controls for differences in the numbers of people claiming refugee status; people holding a study, work or Minister's permit; and/or non-Canadian-born dependants of non-permanent residents.

\section{Empirical Models}

Model A includes standard reform tools and labor market policy tools without other controls. Model B adds macroeconomic factors with one- and two-year lags. Model C adds the main explanatory variables of interest: new reform variables. And Model D adds the four demographic controls. ${ }^{29}$ Model E repeats D but with coarsely coded NEWREFORM in place of the eight finely coded new reform variables. Models that include province fixed effects are labeled "+PFE" and those that include year fixed effects are labeled "+YFE". Specifications with coarsely (i.e., the eight-dimensional representation) and finely (compressed to one dimension) coded representations of new reforms are presented side by side for comparison.

\footnotetext{
${ }^{29}$ Gelbach (2010) cautions that the order in which covariates are added can influence reported results to an extent that is often under-appreciated. Following Gelbach's recommendations, we begin with an empirical model that includes only the policy variables that are already well-established as influences on welfare participation.
} 
Model A includes only welfare benefit levels, eligibility requirements, income and unemployment benefit levels (i.e., the most studied drivers of welfare participation, stacked into the $4 \times 1$ vector $\left.\mathrm{SRT}_{i t}\right)$ :

$$
\mathrm{Y}_{i t}=\alpha+\mathrm{SRT}_{i t}{ }^{\prime} \mu+\varepsilon_{i t},
$$

where $\mathrm{Y}_{i t}$ represents welfare participation rates in province $i$ (ranging from 1 to 10 ) in year $t$ (ranging from 1986 to 2009); and $\alpha$ is a constant; $\mathrm{SRT}_{i t}$ 'represents the transpose of $\mathrm{SRT}_{i t}$; $\mu$ is a $4 \times 1$ vector of coefficients measuring the expected change in welfare participation associated with a one-unit change in each policy variable stacked in $\mathrm{SRT}_{i t}$; and $\varepsilon_{\mathrm{it}}$ represents unobserved heterogeneity uncorrelated with other right-hand-side variables and assumed to have zero mean with a block-diagonal variance matrix allowing for within-province correlation (while assuming between-province independence).

To simplify notation and see the encompassing relationship among the models A through D, an abuse of notation that re-uses Greek symbols which should be denoted with model-specific indexing is used to express the encompassing models below. Model B adds six macroeconomic controls, the 6x1 vector $\mathrm{M}_{i t}$, which includes UNEMPLOYMENT and REALGDPGROWTH contemporaneously and with two lags each:

$$
\mathrm{Y}_{i t}=\alpha+\operatorname{SRT}_{i t}{ }^{\prime} \mu+\mathrm{M}_{i t}{ }^{\prime} \rho+\varepsilon_{i t},
$$

where $\rho$ is a $6 \times 1$ vector of coefficients that represent the marginal effects of the macroeconomic variables on welfare participation. All other symbols are defined as before (with the caveat that each re-used symbol is quantitatively distinct from other models' instances of the same symbol).

Model $\mathrm{C}$ includes the eight new reform variables finely coded, intended to capture multiple dimensions of cross-province and temporal variation in new reform strategies: 


$$
\mathrm{Y}_{i t}=\alpha+\mathrm{SRT}_{i t}{ }^{\prime} \mu+\mathrm{M}_{i t}{ }^{\prime} \rho+\mathrm{NRS}_{i t}{ }^{\prime} \pi+\varepsilon_{i t},
$$

where $\mathrm{NRS}_{i t}$ represents an $8 \mathrm{x} 1$ vector of new reform variables and $\pi$ is an $8 \mathrm{x} 1$ vector of coefficients.

Next, Model D includes the four demographic variables (stacked in the $4 \times 1$ vector $\mathrm{D}_{i t}$ ):

$$
\mathrm{Y}_{i t}=\alpha+\operatorname{SRT}_{i t^{\prime}} \mu+\mathrm{M}_{i t}{ }^{\prime} \rho+\mathrm{NRS}_{i t^{\prime}} \pi+\mathrm{D}_{i t^{\prime}}{ }^{\prime} \kappa+\varepsilon_{i t}
$$

where $\kappa$ is a $4 x 1$ vector of coefficients measuring effects on welfare participation of one-unit changes in each demographic variable.

Province fixed effects (PFE) are the 9x1 vector of coefficients $\lambda$ multiplying province indicators stacked in the $9 \times 1$ vector $\mathrm{L}_{\mathrm{i}}$ (for location i) consisting of time-invariant dummies for all provinces other than Alberta (which serves as the omitted reference class). ${ }^{30}$ Year fixed effects (YFE) are the $23 \times 1$ vector of coefficients $\tau$ multiplying year indicators stacked in the $23 \times 1$ vector $\mathrm{T}_{\mathrm{t}}$ (for time), which consist of dummies for all years other than 1986 (the first year in the sample, which serves as the omitted reference class). The fully encompassing model, with all regressors, province and year fixed effects, is referred to as finely coded Model D+PFE+YFE:

$$
\mathrm{Y}_{i t}=\alpha+\mathrm{SRT}_{i t}{ }^{\prime} \mu+\mathrm{M}_{i t}{ }^{\prime} \rho+\mathrm{NRS}_{i t}{ }^{\prime} \pi+\mathrm{D}_{i t}{ }^{\prime} \kappa+\mathrm{L}_{\mathrm{i}}{ }^{\prime} \lambda+\mathrm{T}_{\mathrm{t}}{ }^{\prime} \tau+\varepsilon_{i t} .
$$

To facilitate comparison with Kneebone and White (2009) and studies using US data with scalar-valued measures of new reforms, we collapse the eight-dimensional representation of new reforms into the scalar-valued variable NEWREFORM, the model labeled E+PFE+YFE:

$$
\mathrm{Y}_{i t}=\alpha+\mathrm{SRT}_{i t}{ }^{\prime} \mu+\mathrm{M}_{i t}{ }^{\prime} \rho+\mathrm{NEWREFORM}_{i t}{ }^{\prime} \pi+\mathrm{D}_{i t}{ }^{\prime} \kappa+\mathrm{L}_{\mathrm{i}}{ }^{\prime} \lambda+\mathrm{T}_{\mathrm{t}}{ }^{\prime} \tau+\varepsilon_{i t},
$$

where NEWREFORM ${ }_{i t}$ takes on the value 1 in province-years with three or more new reform strategies in effect, and 0 otherwise. Five provinces meet this threshold for belonging to the

\footnotetext{
${ }^{30}$ Province fixed effects provide a coarse set of controls for difficult-to-measure differences in provinces' other policies, cultures, and fundamentals such as physical capital per worker (perhaps absorbing too much variation but tending to shrink other estimated effects).
} 
treatment group indicated by NEWREFORM: Alberta (March 1993-), British Columbia (January 2002- ), Ontario (September 1996- ), Prince Edward Island (June 1995-), and Saskatchewan (May 2001- ). Province-years not indicated comprise the control group. ${ }^{31}$ Standard errors are computed using Arellano's (1987) clustered covariance matrix (CCM) technique, which assumes that $\varepsilon_{i t}$ is uncorrelated between provinces but autocorrelated within province. $^{32}$

\section{RESULTS}

Table 5 presents estimates of Models A+PFE+YFE through E+PFE+YFE (i.e., Models A through E with province and year fixed effects). Estimates across each of these models suggest that the wage subsidy (logEI_INDEX) offered by the EI program is positively associated with welfare participation, regardless of model specification. The results imply that EI and welfare are complements in the sense that rates of welfare participation are higher in province-years that provide greater access to income support through EI. This finding confirms previously reported findings in studies of Canadian welfare participation (Finnie and Irvine, 2008). The effect size of 8.16 implies that a one standard deviation change in log of the EI index of 0.10 (an

\footnotetext{
${ }^{31}$ Some accounts raise questions about the stringency of Prince Edward Island's new reforms. Its inclusion in this list of relatively aggressive reformers follows from the algorithmic coding schemes and source materials described above. We acknowledge the possibility that PEI's new reforms were less aggressive than in the other four provinces. ${ }^{32}$ Bertrand et al. (2004) caution that, without proper control for autocorrelation, standard measures of statistical significance are misleading. The CCM standard errors are noticeably larger, shrinking reported $t$ statistics and making it more difficult for the data to pass the threshold of statistical significance. Under classical assumptions for a panel model based on $\mathrm{N}$ units (provinces) observed for $\mathrm{T}$ periods and with $\mathrm{K}$ regressors, the degrees of freedom for t statistics is NT $-\mathrm{K}-1$. Arellano's (1987) method is appropriate when N $>$ T. For the case relevant to the data in this paper where $\mathrm{T}>\mathrm{N}$, however, Hansen (2007) proposes a more conservative formula for degrees of freedom, $\mathrm{N}-$ 1 , when using CCM to control for autocorrelation. How one interprets the t statistics in Tables 5 and 6 (presented in the next section) depends on whether Hansen's or Arellano's distributions for t statistics is assumed. Under classical assumptions with $240-(9+23+22+1)-1=184$ degrees of freedom (based on 9 province fixed effects, 23 year fixed effects, 22 other regressors, and a constant in Model D+PFE+YFE), the well-known critical values 1.65 and 1.98 cut off 2 -sided confidence regions ( 90 and $95 \%$ respectively). Under Hansen's more conservative approach with $10-$ $1=9$ degrees of freedom, the critical $t$ values are 1.83 and 2.26 (for 90 and $95 \%$ confidence levels).
} 
approximate $10 \%$ increase in the EI index) translates into the expected participation rate increasing by 0.816 percentage points.

Welfare benefit levels (as measured by logBENEFITS_SINGLE_ONECHILD) have large effects on welfare participation, although its significance (both economic and statistical) falls once new reforms are included in the model. The coefficients on

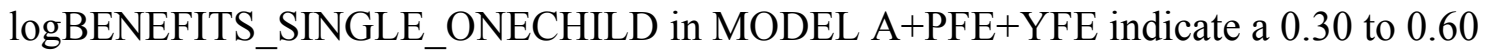
percentage-point increase in welfare participation associated with a $10 \%$ increase in benefit levels. Although the literature on benefit levels is mixed, the benefits effects in Table 5 are consistent with micro-data findings (Allen, 1993) that frequency of child birth, divorce, and welfare participation are positively associated with benefit levels. Another important point of comparison in the benefits literature for interpreting coefficients in Table 5 is Milligan and Stabile (2007), who find that reductions welfare benefits-which occurred in Alberta, Manitoba, Nova Scotia, Ontario, and Prince Edward Island-could account for 19 to $27 \%$ of the decline in welfare participation in those provinces.

In general, Table 5 suggests that labor market tightness, as measured by the unemployment rate of prime-age males (UNEMPLOYMENT) and macroeconomic fluctuations (REALGDPGROWTH), has surprisingly small effects on welfare participation. Though jointly insignificant (and failing to reject that the sum is zero), the UNEMPLOYMENT coefficients pick up a noticeable effect in the $2^{\text {nd }}$-year lag implying that a large 4 to 5 percentage-point difference in unemployment rates could be associated with a one percentage-point difference in the welfare participation rate two years later. Similarly, the sum of coefficients for REALGDPGROWTH and its two lags is statistically indistinguishable from zero in most models. 
Models C+PFE+YFE and D+PFE+YFE show that work requirements are the only of the finely coded new reforms with large and statistically significant effects reducing welfare participation. Estimates from Model D+PFE+YFE for WORKREQ_STRONG suggest that the presence of work requirements with strong sanctions were associated with a reduction in welfare participation of 1.43 percentage points $(\mathrm{t}=3.2)$. Relative to the unconditional mean participation rate of $8.14 \%$, expected participation in province-years with strong work requirements is $17.6 \%$ less $(-1.43 / 8.14=-0.176)$. Work requirements with weak sanctions (WORKREQ_WEAK) also have statistically significant effects on welfare participation (even when applying Hansen's more conservative $\mathrm{N}-1$ degrees of freedom).

The finding that work requirements are associated with reduced welfare participation is in line with the predicted effects of work requirements in Grogger and Karoly's (2005) static labor supply model and matches the empirical findings from US data surveyed in that same volume. Rector and Youssef (1999) and Danielson and Klerman (2008) report (using US data) that strong versus weak sanctions (for non-compliance with work requirements) reduce welfare participation by 16 to $39 \% .^{33}$ Table 5 shows relatively small differences in effect size between strong versus weak enforcement of provinces' work requirements. Effects of diversion (weak or strong) in Table 5 are not estimated precisely enough to be statistically distinguishable from zero, although the information coded in the diversion variables produces more pronounced effects in the distributed lag and dynamic models presented in the next subsection. ${ }^{34}$ Few studies have sought to measure the degree to which diversion affects welfare participation, in part, because

\footnotetext{
${ }^{33}$ For contrasting results, see Hofferth, Stanhope, and Mullan Harris (2002), who find that sanctions had no impact on welfare exit rates. A similar conclusion follows from MaCurdy, Mancuso, and O'Brian-Strain (2002), who conclude that work requirements and sanctions led to no significant reductions in US welfare participation.

${ }^{34}$ Diversion has large-magnitude, negative coefficients when province fixed effects are excluded. Similarly indicative of other regressors absorbing correlated variation in diversion are the bivariate benchmark estimates in Appendix B, which show large negative associations between strong diversion and participation.
} 
differences in diversion strategies across jurisdictions are often too subtle for obvious coding and inclusion in econometric models. Finnie, Irvine and Sceviour (2005) provide evidence, however, suggesting that diversion may have played an important role in reducing entry rates into welfare in Canada. Green and Warburton (2004) examine the impact of tightened eligibility requirements in British Columbia between 1995 and 1996, suggesting that added caseworker scrutiny (one interesting dimension of diversion) led to no long-term reduction in participation.

In Model D+PFE+YFE, time limits are associated with negative, but statistically insignificant, effects on welfare participation, which is unsurprising given that they were present in only 8 of 240 province-years (British Columbia 2002-2009). It is also possible that some welfare participants anticipated the implementation of British Columbia's time limits and exited social assistance prior to its implementation so as to ration eligibility. To investigate this a bit further, we ran a model re-coding TIMELIMITS according to when British Columbia first made public its intentions to limit welfare use (late in 2001), which did not change the qualitative findings. Another explanation for the weak effect of the time limits variable is the subsequent number of exemptions from time limits, which meant that few participants faced binding effects because of the way in which this policy was implemented in Canada. In contrast, US data show strong evidence that lifetime time limits reduced welfare participation (Swann, 2005; Grogger, 2004; and Grogger, Haider and Klerman, 2003).

Model E+PFE+YFE reports estimates using coarsely coded (scalar-valued) NEWREFORM as the only new reform variable. The coefficient of NEWREFORM of 1.08 indicates that province-years with any three new reform strategies have expected participation rates 1.08 percentage points lower than in province-years without. Relative to the unconditional 
mean of 8.14 , this translates to $13 \%$ less welfare participation. ${ }^{35}$ Although the estimated effects of changes in benefit levels have large standard errors, a calculation of the benefit reduction required to generate reductions in participation equivalent to NEWREFORM (dividing the coefficient on NEWREFORM in Model E+PFE+YFE by the coefficient on

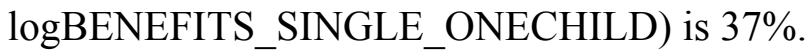

\section{Dynamic Models}

Table 6 presents participation models with 1-year distributed lags of new reform variables, fully differenced models, and dynamic models with lagged participation on the righthand side estimated with the Arellano-Bond estimator. Appendix D reports the same six models as in Table 6 with five-year distributed lags to further investigate the sensitivity of the results in Tables 5 and 6 (namely, that new reforms significantly reduce participation) to longer lag lengths, reflecting the possibility that these policies influence participation with a cumulative response that extends longer than two years. To address the concern that some statistical associations between new reforms and participation may be spurious artifacts of a non-stationary dynamical process generating the participation data, Appendix AR reproduces the qualitative findings using a pre-filtered residual from an AR(1) model (reproduced with both provincespecific and single AR(1) specifications), and Appendix HP reproduces the same findings (with some differences in effects in the finely coded specifications) using participation data de-trended with the Hodrick and Prescott (HP) filter (Hodrick and Prescott, 1997).

Table 6 shows cumulative effects of strong work requirements ranging from -0.74 $(p=0.0000)$ to $-1.99(p=0.0017)$ percentage-point changes in expected participation. In all three

\footnotetext{
${ }^{35}$ Restricting the treatment group to the provinces of Alberta (1993-2009), British Columbia (2002-2009), and Ontario (1996-2009), which likely provides a more accurate comparison with US reform initiatives, produces an effect size for NEWREFORM of $-1.65(|t|=2.9), 50 \%$ larger than the estimate shown in Table 5. This more restrictive treatment group more closely approximates Kneebone and White's (2009) Administrative Procedures variable and the effect size they report.
} 
finely coded specifications, the effect sizes of strong work requirements are stronger at the oneyear lag than contemporaneously. Models with five lags in Appendix D confirm large, statistically significant effects of strong work requirements at the one-year lag with no statistically significant effects from longer lags. Cumulative effects of weak work requirements are smaller in in Table 6 than in Table 5 (with only contemporaneous effects) when comparing fully differenced and Arellano-Bond specifications. Table 6 reveals slightly stronger evidence that diversion is negatively associated with participation. And Table 6 shows suggestive evidence that time limits were implemented in a way that took at least a year to exert downward pressure on participation, although these cumulative effects are mostly indistinguishable from zero with the smallest p-value (associated with the null that the sum of contemporaneous and lagged coefficients is zero) of 0.0862 . In the final three columns of Table 6 (models with coarsely coded NEWREFORM and its lag), cumulative effects range from $-0.58(\mathrm{p}=0.0000)$ to $-1.54(p=0.0331)$ percentage points associated with the presence of new reforms in a given province-year. Large and statistically significant effects on the one-year lag of NEWREFORM, with no statistically significant effects on longer lags, from 5-year distributed lag specifications in Appendix D confirm the range of effect sizes and dynamic effects in Table 6.

A distinct question regarding the dynamics of welfare policy and participation concerns the possibility of endogeneity, where high levels of participation could have caused political support for implementing new reforms. Reverse regression of NEWREFORM (as the dependent variable) on lags of participation produce no statistically significant and positive coefficients. In contrast, models of participation with lags of policy (and the fully set of controls on the righthand side in both cases) support the hypothesis that these policy changes have economically and statistically significant negative associations with observed reductions in participation. There is 
no evidence of reverse causation in the fully differenced, Arellano-Bond or reverse regressions. These models also help address the question of whether reversion to the mean could have generated spurious negative associations between new reforms and subsequent reductions in participation. For example, if unusually high participation rates had caused political support to shift in favor of implementing new reforms, then subsequent reversions of participation to its expected levels could have produced spurious negative associations that do not reflect true negative correlation in the data-generating process. The data reveal no evidence consistent with these hypotheses of spurious correlation. These models also help address the question of whether reversion to the mean could have generated spurious negative associations between new reforms and subsequent reductions in participation. For example, if unusually high participation rates had caused political support to shift in favor of implementing new reforms, then subsequent reversions of participation to its expected levels could have produced spurious negative associations that do not reflect true negative correlation in the data-generating process. The data reveal no evidence consistent with these hypotheses of spurious correlation.

New Reform Strategies' Contribution to Observed Declines in Welfare Participation

Table 7 compares the contributions of four prominent factors thought to have influenced the large observed declines in Canada's welfare participation rate from its peak in 1994 through 2009: new reform strategies, declines in long-run unemployment rates, lower benefit levels, and lower EI wage subsidies. ${ }^{36}$

\footnotetext{
${ }^{36}$ Factors not included in Table 7 (e.g., stricter eligibility requirements and improvements in real income) were not statistically significant. Other omitted factors may have been statistically but not economically significant. Table 7 is modeled after a table in CEA (1999) summarizing the role of US policies in explaining post-1996 declines in US welfare participation. Column (1) shows estimated coefficients from Model D+PFE+YFE in Table 6. Column (2) shows the observed change in the province-specific population-weighted national average of each right-hand-side factor (computed as the 2009 observation minus the 1994 observation of $\mathrm{x}$ ). Column (3) shows the expected change in the welfare participation rate since 1994 based on the observed change in each right-hand-side factor (holding all else equal), computed as the product (or sum of products) of the coefficient(s) in Column (1) and change(s) in $\mathrm{x}$ in Column (2). Column (4) translates expected declines in participation (reported as changes in units of percentage
} 
One basic question is whether the decline in participation was due to welfare reforms, the good luck of positive macroeconomic shocks, or something else as yet unexplained. Table 7 shows that provinces implementing new reforms (measured by the policy variable NEWREFORM) explain about $10 \%$ of the decline in welfare participation during this period. ${ }^{37}$ Declines in the long run unemployment rate (among prime-age males) that occurred between 1994 and 2009 explain only about 6\%. Reductions in welfare benefits (although not statistically significant) explain around 4\% (less than half the effect of adopting new reform strategies). By far, the biggest driver of declines in welfare participation is changes in EI policy. Reducing the EI wage subsidy explains $17 \%$ of the decline in welfare participation. Table 7 implies that new reforms were at least half as effective in reducing welfare participation as cuts in EI and roughly twice as effective as reductions in welfare benefits and tightening eligibility requirements.

Kneebone and White (2009) report that Administrative Procedures (i.e., new reform strategies) in Alberta, British Columbia, and Ontario explain 47 to $65 \%$ of the reduction in welfare participation in those provinces between 1992 and 2003. They also find that changes in the unemployment rate explain only 11 to $21 \%$ of the declines. Their econometric model contains fewer control variables, which matches what emerges from our model with fewer

points in Column (3)) into headcounts measuring the expected number of Canadians prevented from receiving welfare (per year) attributable to changes in $\mathrm{x}$ on the right-hand-side, one factor at a time. Finally, Column (5) reports percentages of the observed decline attributable to each factors, computed as Column (3) divided by the observed percentage point decline in Canada's welfare participation rate of $-6.3(=6.1 \%$ in 2009 minus $12.5 \%$ in 1994).

${ }^{37}$ The more stringent coding scheme for NEWREFORM mentioned in footnote 35 corresponds to the requirement that a province-year have three or more strong new reforms (i.e., three or more nonzero values of WORKREQ_STRONG, DIVERSION_STRONG, TIMELIMITS, or EARNING EXEMPTIONS with both a nonzero exemption level and non-100 percent tax rate). This more stringent coding of NEWREFORM produces an effect size more than $50 \%$ larger $(-1.65,|t|=2.9)$ and explains $15 \%$ of the decline in welfare participation over this period. This result further reinforces the finding from Table 5 pointing to work requirements with strong sanctions as the policy tool with the clearest empirical association with declines in welfare participation among those policy effects estimated precisely enough to achieve statistical significance. Shortening the years covered in the sample in either direction once again increases the effect size and its statistical significance. Yet another statistical question that leads us to think the effect size reported in Table 7 is conservative is the extent to which the model is likely over-parameterized with fixed effects that absorb perhaps too much variation in participation rates thus masking the full effects of new reforms. 
controls or truncation of the sample period to exclude the last half of the 2000s (i.e., larger effects of new reforms associated with reduced participation). Like the findings presented here, US studies generally find that new reforms played a larger role than did reductions in unemployment rates. For instance, CEA (1999) finds that policies under the PRWORA that were comparable to new reform strategies accounted for about $36 \%$ of the decline in welfare participation between 1996 and 1998 while improvements in the unemployment rate accounted for only $8 \%{ }^{38}$

New Reforms and Employment, Employment Rates and the Labor Force

If new reforms succeeded at reducing welfare participation, then one wants to know what happened to those Canadians who were likely prevented from receiving welfare. Appendix E looks for evidence (aggregated once again at the level of province-years) of new reforms affecting employment, employment rates and the labor force. The results are mixed. New reforms were associated with an increase in employment of around $6 \%$ in the coarsely coded $\log ($ EMPLOYMENT) model but negatively associated with employment rates, apparently by increasing the labor force by more than the number employed. Although an economically and statistically significant number of former participants did find work in province-years with NEWREFORM in effect, there was another flow into the labor force of those who would have otherwise been welfare participants but did not find employment, thus, increasing the labor force and decreasing employment rates.

\section{DISCUSSION AND INTERPRETATION}

\footnotetext{
${ }^{38}$ If new reform strategies have their largest effects shortly after implementation, then the much narrower time period in CEA (1999), as compared to the 13-year period of decline examined here, could explain the differences between our findings and those of US studies.
} 
Welfare reform in Canada continues to spark controversy. This paper addresses the descriptive question of whether new reforms actually achieved their stated goal of reducing the number of Canadians on social assistance. The evidence presented in this paper answers that question in the affirmative. Methods of coding new reforms from the publications of provincial governments, the federal government, and third-party accounts of the stringency of welfare reform provide new descriptive measures of the welfare policy environment in Canada. Empirical measures (estimated with data disaggregated at the level of province-years) reveal new information about how welfare participation responded to changes in the multi-dimensional policy environment. Strong requirements and strong diversion are associated with economically and statistically significant declines in participation. The presence of three or more new reforms in a province-year is associated with a 1.08 percentage-point decline in the participation rate and cumulative declines (with large declines at the one-year lag) ranging from of 0.58 to 1.54 percentage points.

This paper introduces empirical measures of four policy variables used to implement new welfare reforms: work requirements with sanctions, diversion, earnings exemptions, and time limits. The empirical models include controls for province-specific macroeconomic conditions (i.e., provincial GDP growth and unemployment rates), employment insurance (which provides transfer payments from a distinct income support program which, in theory, may function either as a substitute or complement to welfare participation), and the more widely studied welfare reform tools, benefit levels and eligibility requirements. Including all these variables in a single econometric model, the results provide empirical information intended to inform debates over potentially competing (but also complementary) explanations for the observed declines in Canada's welfare participation rate. The econometric exercise of encompassing these competing 
explanations (as testable restrictions on coefficients in the encompassing model) allow the data to rank which of these mechanisms had the largest statistical associations with declines in participation (summarized in Table 7). Reductions in employment insurance had the largest effects, followed by new reforms, improvements in unemployment rates and benefit levels. New reform strategies, when coded coarsely as a single variable indicating province-years with three or more new reforms in effect, explain about $10 \%$ of the decline in welfare participation in Canada since 1994, almost twice the effect size for reductions in welfare benefit levels that occurred in most provinces from 1994-2009.

Among new reform strategies, it appears that work requirements with strong sanctions for non-compliance had the largest effects. The presence of strong work requirements is associated with a $27 \%$ reduction in welfare participation. To answer the question posed in the introduction regarding the differential effect of new reform strategies beyond that of benefit levels and eligibility requirements, the data suggest that new reforms were at least as important as, and possibly more important than, reductions in benefit levels and tightening of eligibility requirements.

One important limitation of using data aggregated at the province-year level is that the estimates contain no information regarding differential policy effects for vulnerable subpopulations. Estimating the effects of new reform strategies on particular subpopulations such as immigrants (cf., Baker and Benjamin, 1995), or lengths of welfare spells among childless welfare recipients versus those with children (cf., Barrett and Cragg,1998; Hughes and McCuaig, 2000) will require further analysis micro-level data. The new reform policy measures introduced here will hopefully motivate further statistical investigation using micro-data sources to examine 
how these policy changes influenced rates of entry, exit, and participation among different subpopulations.

\section{REFERENCES}

AB [Government of Alberta] (2009). Alberta Works policy manual.

Acs, G., Phillips, K.R., and Nelson, S. (2005). The road not taken? Changes in welfare entry during the 1990s. Social Science Quarterly 86, 5, 1060-1079.

Allen, D.W. (1993). Welfare and the family: The Canadian experience. Journal of Labor Economics 11,1, S201-S223.

Anderson, M. (1978). Welfare: The political economy of welfare reform in the United States. Stanford, CA: Hoover Institution.

Arellano, M. (1987). Computing robust standard errors for within-groups estimators. Oxford Bulletin of Economics and Statistics 49, 4, 431-434.

Arnau, P., Cremieux, P., and Fortin, P. (2005). The determinants of social assistance rates: evidence from a panel of Canadian provinces. Working paper. Montreal, QC: Departement des science economiques, Unversite du Quebec a Montreal.

Baker, M. and Benjamin, D. (1995). The receipt of transfer payments by immigrants in Canada. Journal of Human Resources 30, 650-676.

Barrett, G. and Cragg, M. (1998). An untold story: The characteristics of welfare use in British Columbia. Canadian Journal of Economics 31, 1, 165-188.

BC [Government of British Columbia] (1999). Ministry of Human Resources annual report, $1997 / 98$.

(2002). Employment and assistance regulation.

Beauchesne, E. (1994, December 23). UI rates continue to tumble, StatsCan reports. The Ottawa Citizen.

Bertrand, M., Duflo, E., and Mullainathan, S. (2004). How much should we trust differences-indifferences estimates? Quarterly Journal of Economics 119, 249-275.

Blank, R.M. (2001). What causes public assistance caseloads to grow? Journal of Human Resources 36, 1, 85-118.

(2002). Evaluating welfare reform in the United States. Journal of Economic Literature 40, 4, 1105-1166.

Boessenkool, K.J. (1997). Back to work: Learning from the Alberta welfare experiment. Toronto, ON: C.D. Howe Institute.

Card, D. and Robins, P. (2005). How important are "entry effects" in financial incentive programs for welfare recipients? Experimental evidence from the Self-Sufficiency Project. Journal of Econometrics 125, 113-139.

CEA [Council of Economic Advisors] (1999). The effects of welfare policy and the economic expansion on welfare caseloads: An update. Washington, DC: Council of Economic Advisors.

Charette, M. and Meng, R. (1994). The determinants of welfare participation of female heads of household in Canada. Canadian Journal of Economics 27,2, 290-306. 
Christofides, L.N. (2000). Social assistance and labour supply. Canadian Journal of Economics $33,3,715-741$.

Christofides, L.N., Stengos, T., and Swidinsky, R. (1997). Welfare participation and labour market behavior in Canada. Canadian Journal of Economics 3, 3, 595-621.

Coelli, M., Green, D., and Warburton, W. (2007). Breaking the cycle? The effect of education on welfare receipt among children of welfare recipients. Journal of Public Economics 91, 13691398.

Danielson, C. and Klerman, J.A. (2008). Did welfare reform cause the caseload decline? Social Service Review 82, 4, 703-730.

Dooley, M.D. (1999). The evolution of welfare participation among Canadian lone mothers, 1973-1991. Canadian Journal of Economics 32, 3, 589-612.

Finnie, R., Irvine, I., and Sceviour, R. (2005). Social assistance use in Canada: National and provincial trends in incidence, entry and exit. No. 246. Ottawa, ON: Statistics Canada.

Finnie, R. and Irvine, I. (2008). The welfare enigma: Explaining the dramatic decline in Canadians' use of social assistance, 1993-2005. Toronto, ON: C.D. Howe Institute.

Gelbach, Jonah (2010). When do covariates matter? And which ones, and how much? Working paper. Tucson, AZ: The University of Arizona.

Gorlick, C.A. and Brethour, G. (1998). Welfare to work. London, ON: University of Western Ontario.

Green, D. and Warburton, W. (2004). Tightening a welfare system: The effects of benefit denial on future welfare receipt. Journal of Public Economics 88, 1471-1493.

Grogger, J. (2004). Time limits and welfare use. Journal of Human Resources 39, 2, 405-424.

Grogger , J., Haider, S., and Klerman, J. (2003). Why did the welfare rolls fall during the 1990's? The importance of entry. AEA Papers and Proceedings 93, 2, 288-292.

Grogger, J. and Karoly, L. (2005). Welfare reform: Effects of a decade of change. Cambridge, MA: Harvard University Press.

Hansen, C.B. (2007). Asymptotic properties of a robust variance matrix estimator for panel data when T is large. Journal of Econometrics 141, 597-620.

Hodrick, R. and Prescott, E. (1997). Postwar U.S. business cycles: An empirical investigation. Journal of Money, Credit and Banking 29, 1, 1-16.

Hofferth, S., Stanhope, S. and Mullan Harris, K. (2002). Exiting welfare in the 1990s: Did public policy influence recipients' behavior? Population Research and Policy Review 21, 433-472.

Holden, A. (1987, October 27). 'Spouse in house' change aids 9,000 single parents. The Toronto Star.

Hughes, C. and McCuaig, K. (2000). When mom must work: Family day care as a welfare-towork option. Toronto, ON: Ontario Coalition for Better Child Care.

HRSDC [Human Resources and Skills Development Canada] (2006). Social assistance statistical report: 2005. Ottawa, ON: Human Resources and Skills Development Canada. (2009). Minimum Wage Database. Ottawa, ON: Human Resources and Skills Development Canada.

Jeffs, A. (1993, March 27). Alberta gets tough on welfare. Calgary Herald.

Klassen, T. and Buchanan, D. (1997). Getting it backward? Economy and welfare in Ontario 1985-1995. Canadian Public Policy 23, 3, 333-338.

Kneebone, R. and White, K. (2009). Fiscal retrenchment and social assistance in Canada. Canadian Public Policy 35, 1, 21-40. 
MaCurdy, T., Mancuso, D., and O'Brien-Strain, M. (2002). Does California's welfare policy explain the slower decline of its caseload? San Francisco, CA: Public Policy Institute of California.

Milligan, K. and Stabile, M. (2007). The integration of child tax credits and welfare: Evidence from the Canadian National Child Benefit program. Journal of Public Economics 91, 305-326.

NB [Government of New Brunswick] (1995). Family Income Security Act. Regulations. (2008). Social assistance policy manual.

NCW [National Council of Welfare] (1987). Welfare in Canada: The tangled safety net. Ottawa, ON: National Council of Welfare. (1990-2008). Welfare Incomes 1989-Welfare Incomes, 2006 and 2007. Ottawa, ON: National Council of Welfare. (1997). Another look at welfare reform. Ottawa, ON: National Council of Welfare.

NS [Government of Nova Scotia] (2008). Policy manual. Employment Support and Income Assistance.

ONCSS [Ministry of Community and Social Services, Government of Ontario] (2008). Ontario Works policy directives.

PEIHSS [Department of Health and Social Services, Government of Prince Edward Island] (2003). P.E.I. social assistance policy manual.

Rector, R. and Youssef, S. (1999). The Determinants of Welfare Caseload Decline. Washington, DC: Heritage Foundation.

Ribar, D. (2005). Transitions from welfare and the employment prospects of low-skill workers. Southern Economic Journal 71, 3: 514-533.

Shannon, M. (2009). Canadian lone mother employment rates, policy change and the US welfare reform literature. Applied Economics 41, 2463-2481.

SK [Government of Saskatchewan] (2002, May 9). Helping low-income people find jobs. News Release.

Statistics Canada (2007). Provincial Economic Accounts. (2009) Income Trends in Canada 1976 to 2007. (2010a). CANSIM in E-STAT. (2010b). Labour Force Survey.

Swann, C. (2005). Welfare reform when recipients are forward looking. Journal of Human Resources 40, 1, 31-56.

Waddell, C. (1989, April 12). Changes to UI scheme pave way for slashed federal contribution. The Globe and Mail.

Wolfe, B. (2002). Incentives, challenges, and dilemmas of TANF: A case study. Journal of Policy Analysis and Management 21, 4, 577-586. 
Table 1: New Welfare Reform Strategies by Implementation Date (1986-2009)

\begin{tabular}{|c|c|c|c|c|c|c|}
\hline & \multicolumn{2}{|c|}{ Work Requirements with Sanctions } & \multicolumn{2}{|c|}{ Diversion } & \multirow[t]{2}{*}{ Earning Exemptions } & \multirow[t]{2}{*}{ Time Limits } \\
\hline Province & $\underline{\text { Weak }}$ & $\underline{\text { Strong }}$ & $\underline{\text { Weak }}$ & $\underline{\text { Strong }}$ & & \\
\hline Alberta & 1'Jan 1991 - Feb 1993 & ${ }^{8}$ Mar 1993 - & & ${ }^{16}$ Mar 1993 - & Jan $1986-$ & \\
\hline British Columbia & ²Jan 1996 - Dec2001 & ${ }^{9}$ Jan 2002 - & ${ }^{12}$ Jan 1996 - Dec2001 & ${ }^{17}$ Jan $2002-$ & ${ }^{19}$ Jan 1986 - Dec 1995 & ${ }^{20}$ Apr $2002-$ \\
\hline Manitoba & ${ }^{3}$ May 1996 - & & & & Jan 1999 - & \\
\hline New Brunswick & ${ }^{4}$ May 1995 - & & & & Jan 1996 - Dec 2004 & \\
\hline \multicolumn{7}{|l|}{ Newfoundland } \\
\hline Nova Scotia & & ${ }^{10}$ Aug 2001 - & ${ }^{13}$ Aug 2001 - & & & \\
\hline Ontario & & ${ }^{11}$ Sep 1996 - & & ${ }^{18}$ Jun 1996 - & Jan 1986 - & \\
\hline Prince Edward Island & ${ }^{5}$ June 1995 - & & ${ }^{14}$ April 1995 - & & Jan 1990 - & \\
\hline Quebec & ${ }^{6}$ Jan 1990 - Sep 1994 & & & & Jan 1986 - Dec 1988 & \\
\hline Saskatchewan & ${ }^{7}$ Jun 1997 - & & ${ }^{15}$ May 2001 - & & Jan 1989 - & \\
\hline
\end{tabular}


Table 1 Source Notes

${ }^{1}$ The Supports for Independence program required welfare participants to look for work or obtain training, and failure to do so resulted in sanctions (NCW, 1992). However, these work requirements had little practical effect because participants could easily appeal the decision and retain benefits at least on an interim basis while waiting for their appeals to be heard (Jeffs, 1993). Therefore, these work requirements are coded as weak.

2 Under the BC Benefits Act welfare participants were required to participate in work-related activity or have their benefits reduced (NCW, 1997).

3 Through the Employment and Income Assistance program welfare participants are required to complete an Action Plan that laid out their work-related responsibilities (NCW, 1997). Failure to fulfill one's Action Plan resulted in a $\$ 50$ sanction, which could rise to $\$ 100$ after six months. Since benefits cannot be fully eliminated, these work requirements are coded as weak.

${ }^{4}$ Under the Family Income Security Act, welfare participants are required to take job training classes, perform a job search, or work (NB, 1995). Otherwise, they will face a reduction in benefits. Since benefits cannot be fully eliminated, these work requirements are coded as weak.

${ }^{5}$ Under the Social Assistance Act welfare participants are required to look for work, attend school, or take part in job training classes (PEIHSS, 2003). Penalties for noncompliance were reportedly infrequent. Therefore, these reforms are coded as weak.

${ }^{6}$ The Act Respecting Income Security provided welfare participants who engaged in work-related activity a bonus of roughly \$100 in additional welfare benefits (NCW, 1997). Since benefits cannot be fully eliminated for non-participation in work-related activities, these "sanctions" are coded as weak.

${ }^{7}$ Under the Saskatchewan Assistance Plan welfare participants are required to set forth a personal transition plan outlining goals and responsibilities that would lead to self-sufficiency (Gorlick and Brethour, 1998). Penalties for noncompliance were reportedly infrequent. Therefore, these work requirements are coded as weak.

${ }^{8}$ The Supports for Independence Program was slowly phased out in favor of the Alberta Works program. Under Alberta Works welfare participants are required to participate in work related activity or face sanctions that either reduced or eliminated benefits (AB, 2009).

${ }^{9}$ The Employment and Assistance Act, which replaces BC Benefits, requires welfare participants to participate in work-related activity or have their benefits reduced by \$100 for two months (if a family with dependent children), or eliminated entirely (if a single adult) (BC, 2002).

${ }^{10}$ The Employment Support and Income Assistance Act requires welfare participants to enter an Employment Action Plan (NS, 2008). The first instance of non-compliance could be sanctioned with a loss of benefits for 6 weeks; repeated non-compliance could result in loss of eligibility to welfare.

${ }^{11}$ Under the Ontario Works program welfare participants who do not participate in mandatory work requirements will have their benefits reduced, or cancelled, for three months at the first instance of non-compliance (ONCSS, 2008). This sanction increases to six months for subsequent offenses.

${ }^{12}$ The BC Benefits Act expected welfare applicants to have pursued all alternate sources of support before gaining access to welfare (BC, 1999). The province was also temporarily successful in requiring new residents to wait three months before becoming eligible for assistance (NCW, 1997). Finally, a short-lived pilot program required some districts to subject welfare applicants to added screening procedures. Despite these and other measures, however, the province demonstrated a questionable ability to enforce eligibility requirements, and are thus coded as weak

${ }^{13}$ Under the Employment Support and Income Assistance Act, welfare applicants are expected to pursue all other "feasible" forms of assistance, such as other government support programs like unemployment insurance benefits, child tax credits, and the like (NS, 2008). If, after evidence provided to case workers suggest the applicant is employable, the applican must show some evidence of job search activity within the past 30 days. If the caseworker is satisfied that sufficient job search has been undertaken, then the applicant can be admitted onto welfare.

${ }^{14}$ The Social Assistance Act requires that welfare applicants be informed of, and be strongly encouraged to pursue, other forms of assistance, such as Employment Insurance and Worker's Compensation benefits, prior to joining welfare (PEIHSS, 2003).

${ }^{15}$ Under the Building Independence umbrella program welfare applicants are now processed through call centers (SK, 2002). Rather than enroll applicants into welfare immediately, callers are alerted to other means of support and, as necessary, diverted to the Jobs First program. The Job First program provides job training services to applicants and informs them of local job opportunities.

${ }^{16}$ Under the Supports for Independence program employable welfare applicants are now required to wait before gaining welfare eligibility (NCW, 1997). The duration is unspecified but applicants may be required to first attend an orientation session before attaining eligibility to welfare. In addition, case workers have the discretion to deny eligibility for employable, single applicants (Boessenkool, 1997). Also, applicants are required to pursue all other forms of assistance, including liquidating their assets. Furthermore, case workers have the discretion to use funds to meet emergency needs other than through enrollment into welfare, such as providing the cost of transportation for applicants who agreed to move to a neighboring province.

${ }^{17}$ The Employment and Assistance Act requires welfare applicants to wait three weeks, during which they were required to attend an orientation session and perform job search before gaining eligibility for welfare (BC, 2002). Also, applicants are not eligible for welfare unless they can show they have worked for two years in succession.

${ }^{18}$ Ontario Works mandates that all welfare applicants pursue all other sources of income before eligibility to welfare can be obtained (ONCSS, 2008). These sources include food banks, untapped spousal support, and the liquidation of assets. Welfare applicants are processed through call centers that put applicants through a screening process. Documentation requirements are extensive.

${ }^{19}$ In addition to 1986-1995, British Columbia again put earnings exemptions in place (temporarily) between 2001 and 2002 (NCW, 2002; 2003 ). In 2003, however, the province eliminated all earning exemptions (NCW, 2004). Since then, welfare participants pay 100 percent tax on all labor market earnings.

${ }^{20}$ In 2002, British Columbia implemented a time limit stipulating that applicants could receive benefits for a maximum of two years out of every five-year period (BC, 2002). Since that time, however, twenty-five classes of individuals have been exempted from such restrictions, including single parents with a child younger than three years of age. 
Table 2: Changes in Welfare Participation Rates* Among Non-Elderly Canadians from 1994 to 2009, by Province

\begin{tabular}{|c|c|c|c|c|}
\hline & $\begin{array}{c}\underline{1994^{* *}} \\
\text { Participation }\end{array}$ & $\stackrel{2009}{\text { Participation }}$ & $\begin{array}{l}\text { Change in } \\
\text { Percentage }\end{array}$ & $\frac{\text { Percentage }}{\text { Change }}$ \\
\hline Province & $\underline{\text { Rate }}$ & $\underline{\text { Rate }}$ & $\underline{\text { Points }}$ & \\
\hline Alberta & 5.7 & 1.9 & -3.7 & -66.1 \\
\hline British Columbia & 11.0 & 4.2 & -6.8 & -61.6 \\
\hline Manitoba & 9.2 & 5.5 & -3.7 & -40.3 \\
\hline New Brunswick & 11.2 & 6.1 & -5.0 & -45.1 \\
\hline Newfoundland & 13.1 & 9.0 & -4.1 & -31.1 \\
\hline Nova Scotia & 12.9 & 5.4 & -7.5 & -58.0 \\
\hline Ontario & 14.5 & 6.7 & -7.8 & -53.7 \\
\hline Prince Edward Island & 11.3 & 4.8 & -6.5 & -57.8 \\
\hline Quebec & 12.4 & 7.3 & -5.1 & -41.0 \\
\hline Saskatchewan & 9.4 & 4.7 & -4.7 & -49.8 \\
\hline
\end{tabular}

* Most spells on welfare among Canadians last less than a year. In British Columbia, for example, Barrett and Cragg (1998) found that most welfare spells end within three months, and only 10 percent of welfare spells last longer than a year (mostly single parents). By contrast, the authors note that roughly 40 percent of spells on welfare in the U.S. last more than two years.

** Canada's national rate of welfare participation peaked in 1994. 
Table 3: Percentage Changes in Real Welfare Benefits (Province-Specific CPIDeflator Adjusted) from 1994 to 2009, by Household Type*

\begin{tabular}{|c|c|c|c|}
\hline \multirow[b]{2}{*}{$\underline{\text { Province }}$} & \multicolumn{3}{|c|}{ Common Household Types } \\
\hline & $\frac{\text { Single, No }}{\underline{\text { Child }}}$ & $\frac{\text { Single Parent, }}{\underline{\text { One Child }}}$ & $\frac{\text { Coupled, Two }}{\underline{\text { Children }}}$ \\
\hline Alberta & 10.1 & 9.1 & -3.8 \\
\hline British Columbia & -14.5 & -7.3 & -11.2 \\
\hline Manitoba & -23.2 & -2.0 & -17.2 \\
\hline New Brunswick & -13.9 & 15.2 & 18.3 \\
\hline Newfoundland & 58.8 & 11.3 & 12.8 \\
\hline Nova Scotia & -22.0 & -8.3 & 3.9 \\
\hline Ontario & -34.3 & -22.7 & -23.5 \\
\hline Prince Edward Island & -30.0 & -1.6 & -4.4 \\
\hline Quebec & -11.6 & 0.6 & 5.2 \\
\hline Saskatchewan & 10.4 & 11.0 & 3.0 \\
\hline
\end{tabular}

*The label single refers to an adult living at an address with no other adults and does not imply anything about marital or relationship status. It is possible for a person classidied as single to be married, unmarried, with a romantic partner, or without, as long as those significant others do not reside at the same address. Similarly, coupled refers to households with two adults living at the same address. In 2008, about 61 percent of adult welfare recipients (excluding those categorized as disabled) were in the category single adult, No Child ; 20 percent were single adults with at least one child; and about 10 percent were coupled with dependent children (HRSDC, 2006). If one includes children, single adult families with at least one child accounts for 36 percent of all welfare participants. The three household types in this table cover most welfare participants and are the most common classifications, they are not exhaustive. 


\begin{tabular}{|c|c|c|c|c|c|}
\hline$\underline{\text { Variables** }}$ & $\underline{\text { Min }}$ & Mean & $\underline{\text { Median }}$ & $\underline{\text { Max }}$ & $\underline{\text { Std Dev }}$ \\
\hline \multicolumn{6}{|l|}{ Dependent Variable*** } \\
\hline PARTICIPATION & 1.57 & 8.14 & 7.91 & 14.67 & 2.79 \\
\hline \multicolumn{6}{|l|}{ Standard Reform Tools } \\
\hline logBENEFITS_SINGLE_ONECHILD & 9.50 & 9.68 & 9.67 & 10.03 & 0.10 \\
\hline logASSET_THRESH & 6.91 & 8.03 & 8.05 & 9.68 & 0.51 \\
\hline \multicolumn{6}{|l|}{ Labor Market Policy Tools } \\
\hline logINCOME_2ndQUINTILE & 10.03 & 10.2 & 10.18 & 10.59 & 0.11 \\
\hline EI_INDEX & 0.33 & 0.65 & 0.57 & 1.26 & 0.29 \\
\hline \multicolumn{6}{|l|}{ Macroeconomic Factors**** } \\
\hline UNEMPLOYMENT & 2.40 & 8.74 & 8.30 & 18.90 & 3.73 \\
\hline REALGDPGROWTH & -10.12 & 2.40 & 2.39 & 15.60 & 2.71 \\
\hline \multicolumn{6}{|l|}{ New Reform Strategies (Finely Coded) } \\
\hline WORKREQ_STRONG & 0.00 & 0.22 & 0.00 & 1.00 & 0.41 \\
\hline WORKREQ_WEAK & 0.00 & 0.25 & 0.00 & 1.00 & 0.43 \\
\hline DIVERSION_STRONG & 0.00 & 0.16 & 0.00 & 1.00 & 0.37 \\
\hline DIVERSION_WEAK & 0.00 & 0.12 & 0.00 & 1.00 & 0.33 \\
\hline TIMELIMITS & 0.00 & 0.03 & 0.00 & 1.00 & 0.18 \\
\hline logEARNINGS_THRESH & 0.00 & 4.27 & 5.05 & 6.10 & 2.04 \\
\hline EARNINGS_TAX & 50.00 & 81.81 & 80.00 & 100.00 & 15.93 \\
\hline \multicolumn{6}{|l|}{ New Reform Strategies (Coarse) } \\
\hline NEWREFORM & 0.00 & 0.28 & 0.00 & 1.00 & 0.45 \\
\hline \multicolumn{6}{|l|}{ Demographics } \\
\hline SINGLEPARENTS & 4.46 & 7.48 & 7.53 & 10.13 & 0.91 \\
\hline MIGRATION & -2.20 & -0.15 & 0.14 & 1.69 & 0.58 \\
\hline DROPOUT & 6.10 & 12.90 & 12.45 & 23.04 & 3.70 \\
\hline NONPERM_RESIDENTS & 0.08 & 0.84 & 0.64 & 3.28 & 0.58 \\
\hline
\end{tabular}

*240 observations are derived from 10 provinces observed at 24 points in time.

** Summary statistics for province fixed effects and year-specific dummy variables included in most versions of the model are not presented here. Inclusion of these indicator variables is indicated in the presentation of regression results.

***PARTICIPATION is the fraction of a province's population age 64 and under receiving welfare benefits in a particular year. Thus, PARTICIPATION is a rate and its units are percentage points, with a theoretical range of 0 to 100, and an empirical range of 1.57 (in Alberta) to 14.67 (in Newfoundland).

****Lagged versions of the macroeconomic variables, UNEMPLOYMENT and REALGDPGROWTH, are included in regression models reported later. Summary statistics for lagged variables are not shown because lagged and unlagged variables have (nearly) identical empirical distributions. 
Table 5: Regression Results with Province and Year Fixed Effects

\begin{tabular}{|c|c|c|c|c|c|c|c|c|c|c|}
\hline \multirow{2}{*}{$\underline{\text { Variables }}$} & \multicolumn{9}{|c|}{ Estimated coefficients and absolute $t$ values for Models: } & \multirow[b]{2}{*}{$\lfloor t$} \\
\hline & $\underline{\mathrm{A}+\mathrm{PFE}+\mathrm{YFE}}$ & $\lfloor t$ & $\underline{\mathrm{B}+\mathrm{PFE}+\mathrm{YFE}}$ & $\lfloor t$ & $\underline{\mathrm{C}+\mathrm{PFE}+\mathrm{YFE}}$ & $\lfloor t$ & $\underline{\mathrm{D}+\mathrm{PFE}+\mathrm{YFE}}$ & $\lfloor t$ & $\underline{\mathrm{E}+\mathrm{PFE}+\mathrm{YFE}}$ & \\
\hline \multicolumn{11}{|l|}{ Standard Reform Tools } \\
\hline logBENEFITS_SINGLE_ONECHILD & 6.32 & 2.7 & 5.80 & 2.6 & 0.89 & 0.3 & 0.83 & 0.3 & 2.95 & 1.4 \\
\hline logASSET_THRESH & -0.07 & 0.2 & 0.03 & 0.1 & -0.05 & 0.3 & 0.00 & 0.0 & 0.24 & 1.1 \\
\hline \multicolumn{11}{|l|}{ Labor Market Policy Tools } \\
\hline logINCOME_2ndQUINTILE & -2.19 & 1.0 & 0.55 & 0.4 & -0.66 & 0.4 & -0.27 & 0.1 & 1.77 & 1.3 \\
\hline logEI_INDEX & 8.61 & 8.1 & 7.37 & 4.3 & 8.24 & 4.8 & 8.65 & 5.5 & 8.16 & 4.9 \\
\hline \multicolumn{11}{|l|}{ Macroeconomic Factors } \\
\hline UNEMPLOYMENT & & & -0.09 & 0.8 & -0.08 & 0.7 & -0.15 & 1.8 & -0.13 & 1.0 \\
\hline UNEMPLOYMENT_\{t-1\} & & & 0.09 & 1.2 & 0.11 & 1.3 & 0.12 & 1.3 & 0.11 & 1.2 \\
\hline UNEMPLOYMENT_\{t-2\} & & & 0.23 & 2.8 & 0.11 & 1.0 & 0.11 & 1.0 & 0.19 & 1.8 \\
\hline REALGDPGROWTH & & & 0.00 & 0.1 & 0.00 & 0.0 & 0.02 & 0.6 & 0.01 & 0.2 \\
\hline REALGDPGROWTH_\{t-1\} & & & -0.03 & 1.7 & -0.03 & 1.6 & -0.03 & 1.3 & -0.04 & 2.1 \\
\hline REALGDPGROWTH_\{t-2\} & & & -0.04 & 1.6 & -0.04 & 1.9 & -0.04 & 1.5 & -0.05 & 1.7 \\
\hline \multicolumn{11}{|l|}{ New Reform Strategies (Finely Coded) } \\
\hline WORKREQ_STRONG & & & & & -1.12 & 2.0 & -1.43 & 3.2 & & \\
\hline WORKREQ_WEAK & & & & & -1.07 & 2.8 & -1.10 & 3.0 & & \\
\hline DIVERSION_STRONG & & & & & -1.34 & 1.4 & -0.83 & 1.0 & & \\
\hline DIVERSION_WEAK & & & & & 0.21 & 0.5 & 0.10 & 0.3 & & \\
\hline TIMELIMITS & & & & & 0.24 & 0.2 & -0.55 & 0.6 & & \\
\hline logEARNINGS_THRESH & & & & & 0.33 & 0.9 & 0.30 & 0.8 & & \\
\hline EARNINGS_TAX & & & & & 0.01 & 0.3 & 0.01 & 0.3 & & \\
\hline THRESH_TAX_INTERACT & & & & & 0.00 & 0.7 & 0.00 & 0.7 & & \\
\hline \multicolumn{11}{|l|}{ New Reform Strategies (Coarse) } \\
\hline NEWREFORM & & & & & & & & & -1.08 & 2.8 \\
\hline \multicolumn{11}{|l|}{ Demographics } \\
\hline SINGLEPARENTS & & & & & & & 0.13 & 1.5 & 0.19 & 1.7 \\
\hline MIGRATION & & & & & & & -0.26 & 1.5 & -0.19 & 0.7 \\
\hline DROPOUT & & & & & & & -0.05 & 1.3 & -0.08 & 2.6 \\
\hline NONPERM_RESIDENTS & & & & & & & 0.33 & 1.2 & 0.08 & 0.2 \\
\hline Constant & -41.96 & 1.3 & -66.24 & 2.0 & -5.45 & 0.2 & -9.21 & 0.3 & -52.37 & 1.7 \\
\hline Province Fixed Effects & Yes & & Yes & & Yes & & Yes & & Yes & \\
\hline Year Fixed Effects & Yes & & Yes & & Yes & & Yes & & Yes & \\
\hline R-Squared & 0.921 & & 0.930 & & 0.951 & & 0.954 & & 0.940 & \\
\hline
\end{tabular}


Table 6: 1-Year Distributed Lag, Fully Differenced and Dynamic Participation Models

\begin{tabular}{|c|c|c|c|c|c|c|c|c|c|c|c|c|}
\hline \multirow[b]{2}{*}{$\frac{\underline{\text { Variables }}}{\text { PARTICIPATION_\{t-1\} }}$} & \multicolumn{6}{|c|}{ finely coded new reforms ( $D+P F E+Y F E$ and augmented dynamic specifications) } & \multicolumn{6}{|c|}{ coarsely coded new reforms (E+PFE+YFE with augmented dynamic specifications) } \\
\hline & distributed lag & t| & $\begin{array}{l}\text { fully } \\
\text { differenced }\end{array}$ & $\lfloor t$ & $\frac{\frac{\text { Arellano- }}{\text { Bond }}}{0.62}$ & $\begin{array}{c}|\mathrm{z}| \\
15.18\end{array}$ & $\frac{\frac{\text { distributed lag }}{E+P F E+Y F E}}{\underline{E}}$ & 丰 & $\begin{array}{l}\text { fully } \\
\text { differenced }\end{array}$ & t| & $\frac{\text { Arellano- }}{\underline{\text { Bond }}}$ & $\begin{array}{c}|\underline{z}| \\
22.5\end{array}$ \\
\hline Standard Reform Tools & & & & & & & & & & & & \\
\hline logBENEFITS_SINGLE_ONECHILD & -0.99 & 0.4 & 2.26 & 1.5 & 0.38 & 0.7 & 2.47 & 1.2 & 3.21 & 1.9 & 1.74 & 3.5 \\
\hline logASSET_THRESH & 0.10 & 1.0 & 0.05 & 0.4 & 0.07 & 0.9 & 0.31 & 1.2 & 0.11 & 0.9 & 0.20 & 2.7 \\
\hline \multicolumn{13}{|l|}{ Labor Market Policy Tools } \\
\hline logINCOME_2ndQUINTILE & 1.86 & 0.8 & 0.23 & 0.3 & -0.19 & 0.2 & 1.99 & 1.2 & 0.05 & 0.1 & -0.06 & 0.1 \\
\hline logEI_INDEX & 8.36 & 5.7 & 1.39 & 2.2 & 3.48 & 6.5 & 8.30 & 5.3 & 1.40 & 2.5 & 2.80 & 5.2 \\
\hline \multicolumn{13}{|l|}{ Macroeconomic Factors } \\
\hline UNEMPLOYMENT & -0.10 & 1.1 & 0.02 & 0.5 & -0.04 & 1.0 & -0.11 & 0.8 & 0.02 & 0.7 & 0.00 & 0.0 \\
\hline UNEMPLOYMENT_\{t-1\} & 0.08 & 0.9 & 0.11 & 2.2 & 0.01 & 0.3 & 0.06 & 0.7 & 0.10 & 2.2 & 0.00 & 0.1 \\
\hline UNEMPLOYMENT_\{t-2\} & 0.21 & 1.9 & 0.11 & 3.3 & 0.04 & 1.1 & 0.26 & 2.2 & 0.10 & 2.3 & 0.01 & 0.3 \\
\hline REALGDPGROWTH & -0.02 & 0.7 & -0.01 & -1.0 & -0.02 & 1.5 & -0.02 & 0.9 & -0.01 & 1.1 & -0.03 & 2.6 \\
\hline REALGDPGROWTH_\{t-1\} & -0.01 & 0.5 & -0.02 & -1.4 & -0.03 & 2.4 & -0.02 & 1.3 & -0.02 & 1.3 & -0.03 & 2.8 \\
\hline REALGDPGROWTH_\{t-2\} & -0.04 & 1.8 & -0.02 & -0.9 & -0.03 & 2.2 & -0.05 & 2.1 & -0.02 & 1.0 & -0.03 & 2.9 \\
\hline \multicolumn{13}{|l|}{ New Reform Strategies (Finely Coded) } \\
\hline WORKREQ_STRONG & -0.40 & 0.6 & 0.07 & 0.2 & -0.26 & 0.9 & & & & & & \\
\hline WORKREQ_STRONG_\{t-1\} & -1.59 & 2.9 & -0.84 & 3.0 & -0.47 & 1.6 & & & & & & \\
\hline cum effect: WORKREQ_STRONG & -1.99 & $(\mathrm{p}=0.0017)$ & -0.77 & $(\mathrm{p}=0.1094)$ & -0.74 & $(\mathrm{p}=0.0000)$ & & & & & & \\
\hline WORKREQ_WEAK & -0.93 & 2.1 & -0.37 & 1.3 & -0.42 & 2.2 & & & & & & \\
\hline WORKREQ_WEAK_\{t-1\} & -0.09 & 0.3 & -0.11 & -0.6 & 0.27 & 1.5 & & & & & & \\
\hline cum effect: WORKREQ_WEAK & -1.02 & $(\mathrm{p}=0.0060)$ & -0.49 & $(\mathrm{p}=0.0552)$ & -0.14 & $(\mathrm{p}=0.0 .1692)$ & & & & & & \\
\hline DIVERSION_STRONG & -0.14 & 0.2 & -1.17 & 3.6 & -0.83 & 2.1 & & & & & & \\
\hline DIVERSION_STRONG_\{t-1\} & -1.14 & 1.3 & -1.11 & 1.4 & 0.10 & 0.3 & & & & & & \\
\hline cum effect: DIVERSION_STRONG & -1.28 & $(\mathrm{p}=0.1380)$ & -2.27 & $(\mathrm{p}=0.0135)$ & -0.73 & $(\mathrm{p}=0.0012)$ & & & & & & \\
\hline DIVERSION_WEAK & 0.45 & 1.0 & -0.07 & 0.3 & -0.01 & 0.0 & & & & & & \\
\hline DIVERSION_WEAK_\{t-1\} & -0.69 & 1.5 & -0.44 & 1.8 & -0.36 & 1.4 & & & & & & \\
\hline cum effect: DIVERSION_WEAK & -0.24 & $(\mathrm{p}=0.3055)$ & -0.51 & $(\mathrm{p}=.1074)$ & -0.37 & $(\mathrm{p}=0.0035)$ & & & & & & \\
\hline TIMELIMITS & 0.97 & 1.2 & 1.13 & 2.3 & 0.69 & 1.3 & & & & & & \\
\hline TIMELIMITS_\{t-1\} & -1.87 & 1.4 & -0.33 & 0.4 & -1.17 & 2.2 & & & & & & \\
\hline cum effect: TIMELIMITS & -0.90 & $(\mathrm{p}=0.4313)$ & 0.80 & $(\mathrm{p}=0.4197)$ & -0.48 & $(\mathrm{p}=0.0862)$ & & & & & & \\
\hline logEARNINGS_THRESH & 0.40 & 1.4 & -0.06 & 0.4 & -0.40 & 3.4 & & & & & & \\
\hline EARNINGS_TAX & 0.03 & 1.2 & -0.01 & 1.9 & -0.04 & 4.1 & & & & & & \\
\hline THRESH_TAX_INTERACT & -0.01 & 1.4 & 0.00 & 0.7 & 0.01 & 3.7 & & & & & & \\
\hline \multirow{2}{*}{\multicolumn{13}{|c|}{ New Reform Strategies (Coarse) }} \\
\hline & & & & & & & & & & & & \\
\hline NEWREFORM & & & & & & & 0.17 & 0.5 & -0.46 & 3.1 & -0.35 & 1.8 \\
\hline NEWREFORM_\{t-1\} & & & & & & & -1.58 & 2.8 & -1.08 & 2.1 & -0.23 & 1.2 \\
\hline cum effect: NEWREFORM & & & & & & & -1.41 & $(\mathrm{p}=0.0237)$ & -1.54 & $(\mathrm{p}=0.0311)$ & -0.58 & $(\mathrm{p}=0.0000)$ \\
\hline \multicolumn{13}{|l|}{ Demographics } \\
\hline SINGLEPARENTS & 0.16 & 2.0 & -0.01 & -0.3 & 0.03 & 0.9 & 0.25 & 2.5 & 0.01 & 0.3 & 0.06 & 1.6 \\
\hline MIGRATION & -0.35 & 1.7 & -0.10 & -1.1 & 0.02 & 0.3 & -0.27 & 0.8 & -0.14 & 1.4 & 0.02 & 0.2 \\
\hline DROPOUT & -0.03 & 0.8 & 0.01 & 0.6 & 0.04 & 1.7 & -0.06 & 1.9 & 0.01 & 0.8 & 0.05 & 2.3 \\
\hline NONPERM_RESIDENTS & 0.06 & 0.2 & 0.03 & 0.1 & 0.60 & 4.1 & 0.07 & 0.2 & 0.12 & 0.4 & 0.35 & 3.1 \\
\hline Constant & -11.51 & 0.3 & 0.87 & 7.3 & -4.09 & 0.4 & -48.42 & 1.5 & 0.82 & 6.1 & -20.08 & 1.9 \\
\hline Province Fixed Effects & Yes & & Yes & & Yes & & Yes & & Yes & & Yes & \\
\hline Year Fixed Effects & Yes & & Yes & & Yes & & Yes & & Yes & & Yes & \\
\hline
\end{tabular}


Table 7: Per-Factor Contribution* to Observed Declines in Welfare Participation, 1994-2009

\begin{tabular}{|c|c|c|c|c|c|}
\hline & $\begin{array}{l}\text { (1) Estimated Coefficient } \\
\text { (b) } \\
\text { from Model E+PFE+YFE }\end{array}$ & $\begin{array}{l}\text { (2) Change in each factor } \\
\text { (Dx) } \\
\text { from } 1994 \text { to } 2009\end{array}$ & $\begin{array}{l}\text { (3) Expected Change in the } \\
\text { Welfare Participation Rate } \\
\text { (bDx) } \\
\text { from } 1994 \text { to 2009, } \\
\text { Per Factor }\end{array}$ & $\begin{array}{l}\text { (4) Expected Number of } \\
\text { Canadians Prevented From } \\
\text { Collecting Welfare } \\
\text { Per Year, Per Factor }\end{array}$ & $\begin{array}{l}\text { (5) Percentage Contribution } \\
\text { to Explaining the } \\
\text { Observed Decline in } \\
\text { Welfare Participation } \\
\text { 1994-2009 }\end{array}$ \\
\hline \multicolumn{6}{|l|}{$\underline{\text { Factor }(\mathrm{x}) * *}$} \\
\hline New Reform Strategies & -1.08 & 0.573 & -0.62 & $-178,452$ & 9.8 \\
\hline Decline in Longrun Unemployment & 0.16 & -2.166 & -0.36 & $-102,950$ & 5.7 \\
\hline Lower Benefit Levels & 2.95 & -0.092 & -0.27 & $-78,476$ & 4.3 \\
\hline Lower EI Wage Subsidy & 8.16 & -0.133 & -1.09 & $-314,981$ & 17.4 \\
\hline Other & & & & & 62.9 \\
\hline
\end{tabular}

* The relative contribution in the last column of this table is the expected decline in welfare participation (from its peak in 1994 through 2009 , given in the third column) divided by the observed (unconditional) decline in welfare participation during that same period, which was -6.3 percentage points.

Column (1) repeats (or, in the case of Longrun Unemployment, computes a simple sum of) coefficients from Model E+PFE+YFE in Table 5 that coarsely bundles new reform strategies into a single polic variable. These coefficients are interpreted as the expected change in the annual rate of welfare participation (in units of percentage points on a zero to 100 scale) conditional on a one-unit change in the right-hand-side factor.

Column (2) computes the 2009-province-population-weighted change in each right-hand-side factor (e.g., the 2009 province-weighted unemployment rate minus the 1994 province-weighted unemployment rate $=-2.166$ ). The change in New Reform Strategies of 0.573 is the fraction of Canadians in 2009 living in a province with new reform strategies in place (provinces in which NEWREFORM = 1) minus the fraction of Canadians in 1994 living in a province with new reform strategies in place.

Column (3) is the product of columns (1) and (2). Column (3) computes the mean Canadian province's expected decline in its annual rate of welfare participation attributable to changes in the right-handside factor from 1994 through 2009. In Column (4),

Column (4), the expected number of Canadians per year prevented from going onto welfare that is associated with observed changes in each $\mathrm{x}$-factor is computed as the expected decline in welfare participation from column (3) translated to headcounts using population data from 2005 (age 64 and under).

Column (5), the per-factor contribution to explaining the observed (unconditional) decline of -6.3 percentage points is computed as the expected decline in column (3) divided by -6.3. A negative contribution implies that the factor changed in a direction which, all else equal, would have increased welfare participation.

** Coefficients for UNEMPLOYMENT, including their lagged counterparts, and logBENEFITS_SINGLE_ONECHILD are on average not significant at either the 90 percent or 95 percent confidence level. Contribution of tightened eligibility requirements (proxied by logASSET_THRESH) and GDP growth omitted due to estimates not having either economic or statistical significance. Likewise, contribution demographical changes have been omitted for clarity. 
Figure 1: Time Paths of Welfare Participation in Canada*

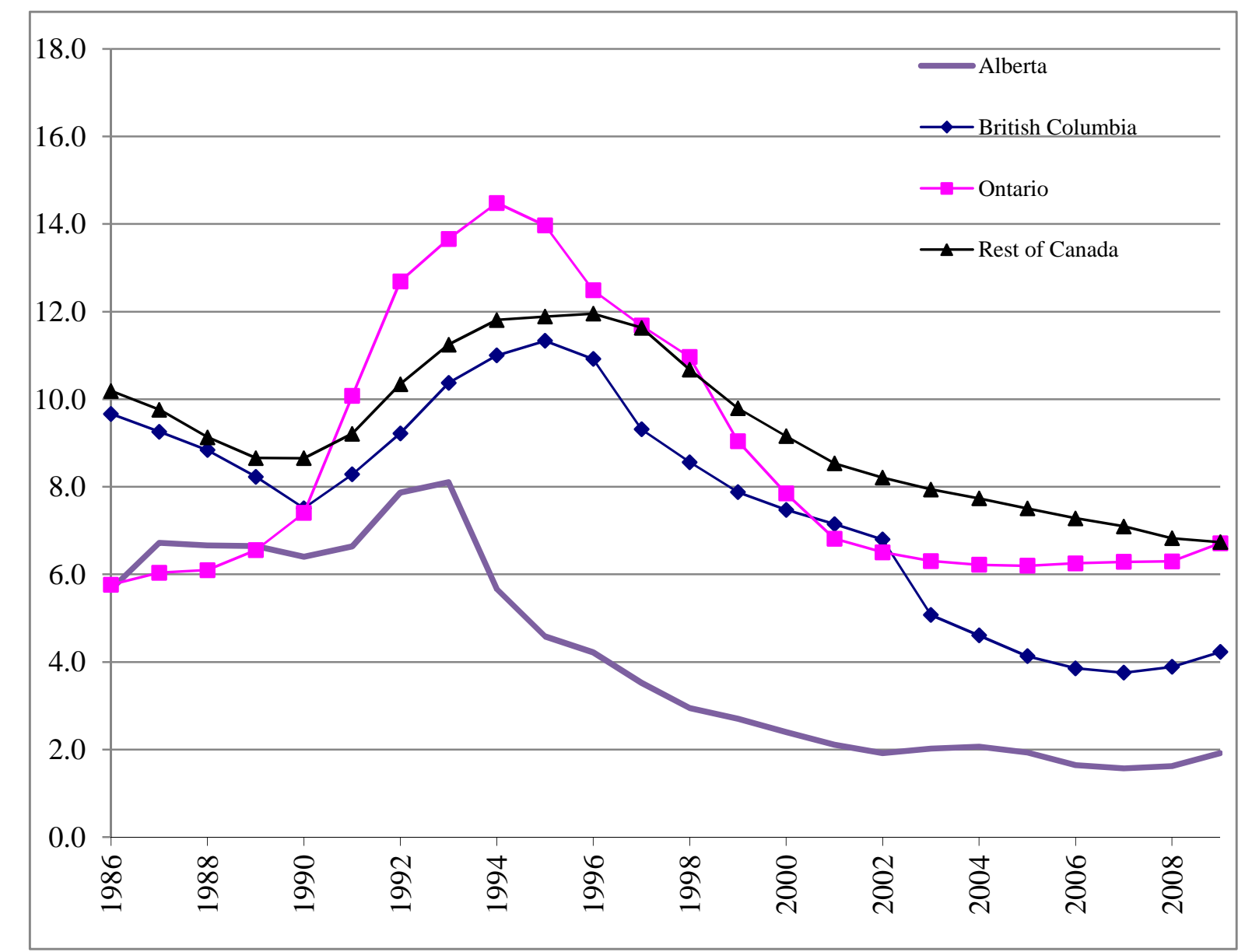

* The large upward trend in Ontario's welfare participation can be traced to a number of factors, including a decision by the province to raise welfare benefit rates every year between 1986 and 1992, as documented by the National Council of Welfare (1991, 1992). 
Appendix B: Bivariate and Other Benchmark Regressions*

\begin{tabular}{|c|c|c|c|c|c|}
\hline \multirow[b]{2}{*}{ Variables } & \multicolumn{5}{|c|}{ Estimated Coefficients and Absolute Value t statistics for Models: } \\
\hline & $\underline{B 1}$ & $|t|$ & Variables & $\underline{B 8}$ & $\lfloor t$ \\
\hline UNEMPLOYMENT & 0.064 & 0.6 & $\mathrm{BC}^{* *}$ & 3.492 & 5.8 \\
\hline UNEMPLOYMENT_\{t-1\} & 0.592 & 4.4 & MB & 2.840 & 4.7 \\
\hline UNEMPLOYMENT_\{t-2\} & -0.132 & 1.0 & NB & 5.236 & 8.7 \\
\hline Constant & 3.048 & 2.7 & NF & 7.190 & 11.9 \\
\hline \multirow[t]{3}{*}{ R-Squared } & 0.516 & & NS & 5.165 & 8.5 \\
\hline & & & ON & 4.534 & 7.5 \\
\hline & $\underline{\mathrm{B}} 2$ & $|t|$ & PEI & 3.696 & 6.1 \\
\hline WORKREQ_STRONG & -3.325 & 3.0 & QC & 5.736 & 9.5 \\
\hline Constant & 8.873 & 15.7 & SK & 2.916 & 4.8 \\
\hline \multirow[t]{3}{*}{ R-Squared } & 0.241 & & Constant & 4.064 & 9.5 \\
\hline & & & R-Squared & 0.455 & \\
\hline & $\underline{\mathrm{B}}$ & $|t|$ & & & \\
\hline WORKREQ_WEAK & $1 . \overline{137}$ & 1.4 & & $\underline{\mathrm{B} 9}$ & \lfloor \\
\hline Constant & 8.432 & 10.7 & $1987 * * *$ & $0 . \overline{145}$ & $\overrightarrow{0.8}$ \\
\hline \multirow[t]{3}{*}{ R-Squared } & 0.031 & & 1988 & -0.115 & 0.5 \\
\hline & & & 1989 & -0.371 & 1.1 \\
\hline & B4 & $|t|$ & 1990 & -0.277 & 0.6 \\
\hline DIVERSION_STRONG & -3.801 & 2.7 & 1991 & 0.576 & 1.0 \\
\hline Constant & 8.755 & 17.4 & 1992 & 1.805 & 2.5 \\
\hline \multirow[t]{3}{*}{ R-Squared } & 0.250 & & 1993 & 2.590 & 3.5 \\
\hline & & & 1994 & 2.742 & 3.3 \\
\hline & $\underline{B 5}$ & $|t|$ & 1995 & 2.536 & 2.9 \\
\hline DIVERSION_WEAK & -1.363 & 1.5 & 1996 & 2.253 & 2.7 \\
\hline Constant & 8.313 & 11.9 & 1997 & 1.745 & 2.1 \\
\hline \multirow[t]{3}{*}{ R-Squared } & 0.026 & & 1998 & 1.011 & 1.3 \\
\hline & & & 1999 & 0.200 & 0.3 \\
\hline & $\underline{B} 6$ & $|t|$ & 2000 & -0.424 & 0.6 \\
\hline TIME_LIMITS & -3.727 & 5.8 & 2001 & -0.980 & 1.5 \\
\hline Constant & 8.268 & 12.8 & 2002 & -1.329 & 2.1 \\
\hline \multirow{2}{*}{ R-Squared } & 0.058 & & 2003 & -1.698 & 2.4 \\
\hline & & & 2004 & -1.860 & 2.6 \\
\hline NEWREFORM (coarsely coded) & -3.302 & 3.6 & 2005 & -2.077 & 2.8 \\
\hline Constant & 9.078 & 18.2 & 2006 & -2.31972 & 3.11 \\
\hline \multirow[t]{3}{*}{ R-Squared } & 0.283 & & 2007 & -2.5382 & 3.46 \\
\hline & & & 2008 & -2.75567 & 3.94 \\
\hline & B7 & $|t|$ & 2009 & -2.73951 & 3.93 \\
\hline logBENEFITS_SINGLE_ONECHILD & 12.052 & 2.2 & Constant & 8.306 & 12.3 \\
\hline Constant & -108.442 & 2.1 & R-Squared & 0.396 & \\
\hline R-Squared & 0.183 & & & & \\
\hline
\end{tabular}

* Models B1 through B9 were all estimated using OLS with the cluster command to control for within-province correlation of provinceyear error terms.

** The province of Alberta, which was the earliest and likely the province with the most aggressive welfare reforms, is the omitted

dummy in the model and therefore the reference point for interpreting estimated values of province effects. All provinces are associated

with a significantly greater proportion of its non-elderly population receiving welfare payments.

*** The year 1986 is omitted so that the estimates reflect a time trend for all years relative to the first. 
Appendix D: 5-Year Distributed Lag, Fully Differenced and Dynamic Participation Models

\begin{tabular}{|c|c|c|c|c|c|c|c|c|c|c|c|c|}
\hline \multirow[b]{2}{*}{$\begin{array}{c}\text { Variables } \\
\text { PARTICIPATION_\{t-1\} }\end{array}$} & \multicolumn{6}{|c|}{ finely coded new reforms ( $D+P F E+Y F E$ and augmented dynamic specifications) } & \multicolumn{6}{|c|}{ coarsely coded new reforms (D+PFE+YFE and augmented dynamic specifications) } \\
\hline & distributed lag & t & $\begin{array}{c}\text { fully } \\
\text { differenced }\end{array}$ & t & $\frac{\frac{\text { Arellano-- }}{\frac{\text { Bond }}{0.78}}}{\text {. }}$ & $\begin{array}{c}\mid \underline{|z|} \\
15.3\end{array}$ & distributed lag & tt & $\begin{array}{l}\text { fully } \\
\text { differenced }\end{array}$ & ț & $\frac{\frac{\text { Arellano- }}{\frac{\text { Bond }}{0.75}}}{-}$ & $\begin{array}{c}\underline{|z|} \\
20.1\end{array}$ \\
\hline Standard Reform Tools & & & & & & & & & & & & \\
\hline $\begin{array}{l}\text { logBENEFITS_SINGLE_ONECHILD } \\
\text { logASSET_THRESH }\end{array}$ & -0.24 & $\begin{array}{l}0.1 \\
1.3\end{array}$ & $\begin{array}{l}1.64 \\
0.03\end{array}$ & $\begin{array}{l}1.1 \\
0.2\end{array}$ & $\begin{array}{r}2.51 \\
-0.05\end{array}$ & $\begin{array}{l}3.6 \\
0.6\end{array}$ & 4.16 & 2.1 & $\begin{array}{l}3.14 \\
0.07\end{array}$ & $\begin{array}{l}1.7 \\
0.5\end{array}$ & 1.97 & 3.5 \\
\hline IOgASSEI_IHRESH & -0.20 & & & 0.2 & & 0.6 & 0.13 & & & & 0.11 & 1.3 \\
\hline $\begin{array}{c}\text { Labor Market Policy Tools } \\
\text { logINCOME_ndQUINTILE } \\
\text { logEI__NDEX }\end{array}$ & $\begin{array}{l}6.27 \\
6.62\end{array}$ & $\begin{array}{l}3.2 \\
7.2\end{array}$ & $\begin{array}{l}1.41 \\
1.10\end{array}$ & $\begin{array}{l}1.4 \\
1.0\end{array}$ & $\begin{array}{c}-1.43 \\
3.07\end{array}$ & $\begin{array}{l}1.2 \\
4.3\end{array}$ & $\begin{array}{l}3.88 \\
9.43\end{array}$ & $\begin{array}{l}1.8 \\
4.0\end{array}$ & $\begin{array}{l}0.19 \\
1.42\end{array}$ & $\begin{array}{l}0.1 \\
1.4\end{array}$ & $\begin{array}{c}-0.43 \\
3.75\end{array}$ & $\begin{array}{l}0.4 \\
5.3\end{array}$ \\
\hline \multirow{2}{*}{\multicolumn{13}{|c|}{ Macroeconomic Factors }} \\
\hline UNEMPLOYMENT & & & & & -0.09 & 1.9 & -0.16 & 1.1 & 0.02 & 0.4 & -0.07 & 1.3 \\
\hline UNEMPLOYMENT_\{t-1\} & 0.10 & 1.2 & 0.08 & 1.5 & -0.01 & 0.2 & 0.01 & 0.1 & 0.10 & 2.2 & -0.03 & 0.7 \\
\hline UNEMPLOYMENT_\{t-2\} & 0.20 & 2.3 & 0.07 & 1.7 & -0.04 & 1.0 & 0.21 & 2.0 & 0.10 & 1.8 & -0.01 & 0.2 \\
\hline REALGDPGROWTH & -0.01 & 0.6 & -0.02 & 1.6 & -0.02 & 1.3 & -0.01 & 0.7 & -0.01 & 1.0 & -0.03 & 2.5 \\
\hline REALGDPGROWTH_\{t-1\} & -0.02 & 0.7 & -0.05 & 1.6 & -0.03 & 2.2 & -0.04 & 1.5 & -0.02 & 1.0 & -0.04 & 2.8 \\
\hline REALGDPGROWTH_\{t-2\} & -0.03 & 1.3 & -0.01 & 0.4 & -0.01 & 0.9 & -0.05 & 1.6 & -0.01 & 0.6 & -0.03 & 2.6 \\
\hline \multicolumn{13}{|l|}{ New Reform Strategies (Finely Coded) } \\
\hline WORKREQ_STRONG & 0.95 & 1.8 & 0.27 & 0.4 & 0.60 & 1.6 & & & & & & \\
\hline WORKREQ_STRONG_\{t-1\} & -1.22 & 2.9 & -1.12 & 1.8 & -1.19 & 3.3 & & & & & & \\
\hline WORKREQ_STRONG_\{t-2\} & -0.40 & 1.1 & -0.44 & 1.0 & 0.47 & 1.3 & & & & & & \\
\hline WORKREQ_STRONG_\{t-3\} & 0.03 & 0.2 & -0.05 & 0.2 & 0.41 & 1.1 & & & & & & \\
\hline WORKREQ_STRONG_\{t-4\} & -0.25 & 1.0 & -0.14 & 1.1 & -0.15 & 0.4 & & & & & & \\
\hline WORKREQ_STRONG_\{t-5\} & 0.06 & 0.2 & -0.12 & 0.6 & -0.03 & 0.1 & & & & & & \\
\hline cum effect: WORKREQ_STRONG & -0.83 & $(\mathrm{p}=0.0615)$ & -0.85 & $(\mathrm{p}=0.3742)$ & -0.60 & $(\mathrm{p}=0.6909)$ & & & & & & \\
\hline DIVERSION_STRONG & -1.79 & 2.4 & -1.36 & 2.5 & -1.30 & 2.8 & & & & & & \\
\hline DIVERSION_STRONG_\{t-1\} & -1.53 & 2.0 & -1.00 & 1.0 & -0.01 & 0.0 & & & & & & \\
\hline DIVERSION_STRONG_\{t-2\} & 0.66 & 1.0 & 0.38 & 0.5 & 1.29 & 2.5 & & & & & & \\
\hline DIVERSION_STRONG_\{t-3\} & -0.11 & 0.2 & -0.63 & 1.0 & -1.01 & 1.9 & & & & & & \\
\hline DIVERSION_STRONG_\{t-4\} & -0.43 & 1.5 & -0.37 & 1.6 & 0.10 & 0.2 & & & & & & \\
\hline DIVERSION_STRONG_\{t-5\} & 0.35 & 0.6 & -0.12 & 0.3 & 0.57 & 1.3 & & & & & & \\
\hline cum effect: DIVERSION_STRONG & -2.84 & $(\mathrm{p}=0.0019)$ & -2.36 & $(\mathrm{p}=0.1290)$ & -1.31 & $(\mathrm{p}=0.3219)$ & & & & & & \\
\hline TIMELIMITS & 1.40 & 1.7 & 1.25 & 1.6 & 0.57 & 1.0 & & & & & & \\
\hline TIMELIMITS_\{t-1\} & 1.78 & 1.3 & 0.36 & 0.3 & 0.14 & 0.1 & & & & & & \\
\hline TIMELIMITS_\{t-2\} & -1.25 & 1.8 & -0.82 & 1.1 & -0.42 & 0.6 & & & & & & \\
\hline TIMELIMITS_ $\{\mathrm{t}-3\}$ & 0.70 & 1.0 & 0.48 & 0.6 & 1.19 & 1.7 & & & & & & \\
\hline TIMELIMITS_ $\{\mathrm{t}-4\}$ & 0.67 & 1.7 & 0.52 & 1.6 & 0.08 & 0.1 & & & & & & \\
\hline TIMELIMITS_\{t-5\} & 0.29 & 0.4 & 0.12 & 0.3 & -0.65 & 1.1 & & & & & & \\
\hline cum effect: TIMELIMITS & 3.60 & $(\mathrm{p}=0.0226)$ & 1.61 & $(\mathrm{p}=0.5480)$ & 0.71 & $(\mathrm{p}=0.2186)$ & & & & & & \\
\hline logEARNINGS_THRESH & -0.30 & 1.2 & -0.16 & 1.1 & -0.28 & 2.0 & & & & & & \\
\hline EARNINGS_TAX & -0.03 & 1.6 & -0.02 & 2.7 & -0.04 & 2.7 & & & & & & \\
\hline THRESH_TAX_INTERACT & 0.01 & 1.4 & 0.00 & 1.4 & 0.01 & $\begin{array}{c}2.1 \\
(\mathrm{n}=00030)\end{array}$ & & & & & & \\
\hline \multirow{2}{*}{\multicolumn{13}{|c|}{ New Reform Strategies (Coarse) }} \\
\hline & & & & & & & 0.02 & 0.1 & -0.57 & 3.3 & -0.44 & 2.3 \\
\hline NEWREFORM_\{t-1\} & & & & & & & $\begin{array}{l}-1.39 \\
-1.39\end{array}$ & 2.2 & -1.12 & 2.1 & $\begin{array}{l}-0.44 \\
-0.75\end{array}$ & 2.9 \\
\hline NEWREFORM_\{t-2\} & & & & & & & 0.27 & 0.7 & -0.43 & 1.6 & 0.51 & 1.8 \\
\hline NEWREFORM_ $\{t-3\}$ & & & & & & & -0.69 & 1.6 & -0.12 & 0.5 & 0.23 & 0.8 \\
\hline NEWREFORM_ $\{t-4\}$ & & & & & & & 0.25 & 0.7 & -0.37 & 1.7 & -0.29 & 1.1 \\
\hline NEWREFORM_\{t-5\} & & & & & & & 0.00 & 0.0 & -0.16 & 1.3 & 0.13 & 0.7 \\
\hline cum effect: NEWREFORM & & & & & & & -1.54 & $(\mathrm{p}=0.0191)$ & -2.78 & $(\mathrm{p}=0.0187)$ & -0.62 & $(p=0.0002)$ \\
\hline \multicolumn{13}{|l|}{ Demographics } \\
\hline SINGLEPARENTS & 0.03 & 0.3 & 0.00 & 0.1 & 0.05 & 1.2 & 0.14 & 1.7 & -0.01 & 0.2 & 0.02 & 0.5 \\
\hline MIGRATION & -0.34 & 1.3 & -0.16 & 1.2 & -0.03 & 0.4 & -0.52 & 1.5 & -0.26 & 1.6 & -0.08 & 1.0 \\
\hline DROPOUT & 0.01 & 0.2 & 0.00 & 0.3 & 0.02 & 0.7 & -0.02 & 0.5 & 0.00 & 0.2 & 0.03 & 1.5 \\
\hline NONPERM_RESIDENTS & -0.69 & 1.7 & -0.02 & 0.0 & 0.50 & 2.6 & -0.47 & 1.4 & -0.01 & 0.0 & 0.25 & 1.8 \\
\hline Constant & -57.12 & 1.8 & 1.10 & 7.3 & -7.15 & 0.6 & -81.35 & 2.6 & -0.22 & 1.0 & -14.51 & 1.2 \\
\hline Province Fixed Effects & Yes & & Yes & & Yes & & Yes & & Yes & & Yes & \\
\hline Year Fixed Effects & Yes & & Yes & & Yes & & Yes & & Yes & & Yes & \\
\hline
\end{tabular}


Appendix E: Log(\# Employed), Employment Rate and Log(\# Labour Force)

\begin{tabular}{|c|c|c|c|c|c|c|c|c|c|c|c|c|}
\hline \multirow{2}{*}{$\begin{array}{c}\text { dependent variable: } \\
\underline{\text { Variables }}\end{array}$} & \multicolumn{5}{|c|}{ finely coded new reforms } & $\operatorname{logLABOURFORCE}$ & $\operatorname{logEMPLOYMENT}$ & \multicolumn{4}{|c|}{ coarsely coded new reforms } & $\log L A B O U R F O R C E$ \\
\hline & $\underline{\mathrm{D}+\mathrm{PFE}+\mathrm{YFE}}$ & $\mid t$ & $\underline{\mathrm{D}+\mathrm{PFE}+\mathrm{YFE}}$ & \pm & $\underline{\mathrm{D}+\mathrm{PFE}+\mathrm{YFE}}$ & t| & $\mathrm{E}+\mathrm{PFE}+\mathrm{YFE}$ & $|t|$ & $\underline{\mathrm{E}+\mathrm{PFE}+\mathrm{YFE}}$ & $|t|$ & $\underline{\mathrm{E}+\mathrm{PFE}+\mathrm{YFE}}$ & tt \\
\hline Standard Reform Tools & & & & & & & & & & & & \\
\hline logBENEFITS_SINGLE_ONECHILD & 0.09 & 1.4 & 3.27 & 2.0 & 0.04 & 0.5 & 0.01 & 0.2 & 5.17 & 2.3 & -0.09 & 1.2 \\
\hline logASSET_THRESH & 0.01 & 1.0 & -0.11 & 0.3 & 0.02 & 1.4 & -0.01 & 0.8 & 0.12 & 0.3 & -0.01 & 0.8 \\
\hline \multicolumn{13}{|l|}{ Labor Market Policy Tools } \\
\hline logINCOME_2ndQUINTILE & 0.40 & 2.4 & 4.52 & 2.1 & 0.30 & 1.9 & 0.37 & 1.6 & 8.88 & 2.6 & 0.19 & 0.8 \\
\hline logEI_INDEX & -0.17 & 2.9 & -10.55 & 7.8 & 0.02 & 0.3 & -0.19 & 2.1 & -9.94 & 5.5 & -0.01 & 0.1 \\
\hline \multicolumn{13}{|l|}{ Macroeconomic Factors } \\
\hline REALGDPGROWTH & 0.00 & 0.5 & 0.01 & 0.3 & 0.00 & 1.0 & 0.00 & 0.4 & 0.01 & 0.4 & 0.00 & 0.7 \\
\hline REALGDPGROWTH_\{t-1\} & 0.00 & 0.2 & 0.04 & 2.7 & 0.00 & 0.4 & 0.00 & 0.6 & 0.03 & 2.7 & 0.00 & 0.3 \\
\hline REALGDPGROWTH_\{t-2\} & 0.00 & 0.4 & 0.06 & 2.5 & 0.00 & 1.1 & 0.00 & 0.9 & 0.07 & 2.5 & 0.00 & 0.1 \\
\hline \multicolumn{13}{|l|}{ New Reform Strategies (Finely Coded) } \\
\hline WORKREQ_STRONG & 0.03 & 0.8 & 0.73 & 1.1 & 0.02 & 0.4 & & & & & & \\
\hline WORKREQ_WEAK & -0.01 & 0.9 & 0.95 & 1.8 & -0.03 & 1.5 & & & & & & \\
\hline DIVERSION_STRONG & 0.10 & 3.1 & -1.55 & 2.0 & 0.12 & 3.1 & & & & & & \\
\hline DIVERSION̄_WEAK & 0.01 & 0.3 & -0.97 & 2.3 & 0.01 & 0.5 & & & & & & \\
\hline TIMELIMITSS & -0.08 & 2.5 & -2.63 & 2.8 & -0.05 & 1.5 & & & & & & \\
\hline logEARNINGS_THRESH & -0.02 & 1.4 & 0.66 & 2.7 & -0.03 & 2.2 & & & & & & \\
\hline EARNINGS_TAX & 0.00 & 0.6 & 0.05 & 4.1 & 0.00 & 1.9 & & & & & & \\
\hline THRESH_TAX_INTERACT & 0.00 & 1.2 & -0.01 & 2.1 & 0.00 & 1.9 & & & & & & \\
\hline \multicolumn{13}{|l|}{ New Reform Strategies (Coarsely Coded) } \\
\hline NEWREFORM & & & & & & & 0.06 & 2.1 & -0.92 & 1.9 & 0.06 & 1.9 \\
\hline \multicolumn{13}{|l|}{ Demographics } \\
\hline SINGLEPARENTS & 0.00 & 0.2 & 0.00 & 0.0 & 0.00 & 0.3 & -0.01 & 1.5 & 0.17 & 1.5 & -0.02 & 1.9 \\
\hline MIGRATION & -0.01 & 1.3 & 0.70 & 4.6 & -0.01 & 1.9 & -0.01 & 0.9 & 0.89 & 3.8 & -0.02 & 1.2 \\
\hline DROPOUT & 0.00 & 1.4 & -0.10 & 1.4 & 0.01 & 2.6 & 0.01 & 2.7 & -0.19 & 2.1 & 0.01 & 3.2 \\
\hline NONPERM_RESIDENTS & 0.06 & 2.3 & -0.56 & 1.0 & 0.07 & 2.2 & 0.03 & 1.7 & -1.05 & 1.1 & 0.05 & 1.5 \\
\hline Constant & 2.07 & 1.3 & 2.59 & 0.1 & -0.83 & 0.7 & 3.45 & 1.4 & -58.41 & 1.4 & 1.77 & 0.7 \\
\hline Province Fixed Effects & Yes & & Yes & & Yes & & Yes & & Yes & & Yes & \\
\hline Year Fixed Effects & Yes & & Yes & & Yes & & Yes & & Yes & & Yes & \\
\hline
\end{tabular}


Appendix AR: AR(1) Pre-Filtered PARTICIPATION, 1-Year Distributed Lag and Dynamic Participation Models

\begin{tabular}{|c|c|c|c|c|c|c|c|c|}
\hline \multirow[b]{3}{*}{$\underline{\text { Variables }}$} & \multicolumn{4}{|c|}{ coarsely coded new reforms } & \multicolumn{4}{|c|}{ coarsely coded new reforms with 1-year lag } \\
\hline & & & Arellano- & & & & Arellano- & \\
\hline & distributed lag & $\mid t$ & Bond & $\underline{\mathrm{z}}$ & $\underline{\text { distributed lag }}$ & $\mid t$ & Bond & $\underline{\mathrm{z}}$ \\
\hline AR1_residual_PARTICIPATION_\{t-1\} & & & 0.19 & 2.7 & & & 0.18 & 2.6 \\
\hline \multicolumn{9}{|l|}{ Standard Reform Tools } \\
\hline logBENEFITS_SINGLE_ONECHILD & 0.87 & 1.1 & 1.10 & 1.8 & 0.93 & 1.2 & 1.21 & 1.9 \\
\hline logASSET_THRESH & 0.11 & 0.9 & 0.14 & 1.5 & 0.11 & 0.8 & 0.15 & 1.6 \\
\hline \multicolumn{9}{|l|}{ Labor Market Policy Tools } \\
\hline logINCOME_2ndQUINTILE & -0.72 & 0.5 & -1.43 & 1.3 & -0.68 & 0.5 & -1.48 & 1.3 \\
\hline logEI_INDEX & 0.78 & 1.5 & 0.99 & 1.5 & 0.76 & 1.4 & 0.94 & 1.4 \\
\hline \multicolumn{9}{|l|}{ Macroeconomic Factors } \\
\hline UNEMPLOYMENT & 0.04 & 0.8 & 0.03 & 0.6 & 0.04 & 0.8 & 0.04 & 0.1 \\
\hline UNEMPLOYMENT_\{t-1\} & 0.02 & 0.5 & -0.01 & 0.2 & 0.02 & 0.6 & 0.00 & 2.0 \\
\hline UNEMPLOYMENT_\{t-2\} & -0.06 & 1.6 & -0.08 & 1.9 & -0.06 & 1.7 & -0.09 & 1.9 \\
\hline REALGDPGROWTH & -0.04 & 2.6 & -0.03 & 2.1 & -0.04 & 2.5 & -0.03 & 1.6 \\
\hline REALGDPGROWTH_\{t-1\} & -0.04 & 1.3 & -0.03 & 1.8 & -0.04 & 1.3 & -0.02 & 0.9 \\
\hline REALGDPGROWTH_\{t-2\} & -0.02 & 1.5 & -0.01 & 0.9 & -0.03 & 1.5 & -0.01 & 0.0 \\
\hline \multicolumn{9}{|l|}{ New Reform Strategies (Coarse) } \\
\hline NEWREFORM & -0.34 & 2.3 & -0.33 & 1.8 & -0.59 & 4.7 & -0.54 & 2.3 \\
\hline NEWREFORM_\{t-1\} & & & & & 0.30 & 1.8 & 0.20 & 0.9 \\
\hline cum effect: NEWREFORM & & & & & -0.30 & $(p=0.0837)$ & -0.34 & $(p=0.0224)$ \\
\hline \multicolumn{9}{|l|}{ Demographics } \\
\hline SINGLEPARENTS & 0.02 & 0.5 & -0.02 & 0.4 & 0.02 & 0.5 & -0.02 & 0.5 \\
\hline MIGRATION & 0.15 & 1.1 & 0.08 & 0.9 & 0.15 & 1.2 & 0.08 & 0.8 \\
\hline DROPOUT & 0.05 & 1.6 & 0.05 & 1.8 & 0.05 & 1.6 & 0.05 & 1.8 \\
\hline NONPERM_RESIDENTS & 0.60 & 3.1 & 0.42 & 2.9 & 0.59 & 3.0 & 0.42 & 2.9 \\
\hline Constant & -12.51 & 0.3 & 2.25 & 0.2 & -4.16 & 0.3 & 1.58 & 0.1 \\
\hline Province Fixed Effects & Yes & & Yes & & Yes & & Yes & \\
\hline Year Fixed Effects & Yes & & Yes & & Yes & & Yes & \\
\hline
\end{tabular}


Appendix HP: Deviation-From-HP-Filtered-Trend-Participation, 1-Year Distributed Lag and Dynamic HP-Deviation-Participation Models

\begin{tabular}{|c|c|c|c|c|c|c|c|c|}
\hline \multirow[b]{2}{*}{$\underline{\text { Variables }}$} & \multicolumn{4}{|c|}{ coarsely coded new reforms } & \multicolumn{4}{|c|}{ coarsely coded new reforms with 1-year lag } \\
\hline & $\underline{\text { distributed lag }}$ & $\lfloor t$ & $\frac{\text { Arellano- }}{\underline{\text { Bond }}}$ & $\mid \mathrm{z}$ & distributed lag & $t$ & $\frac{\text { Arellano- }}{\underline{\text { Bond }}}$ & $\lfloor\underline{z}$ \\
\hline HP_deviation_PARTICIPATION_\{t-1\} & & & 0.69 & 20.3 & & & 0.69 & 19.5 \\
\hline \multicolumn{9}{|l|}{ Standard Reform Tools } \\
\hline logBENEFITS_SINGLE_ONECHILD & 2.45 & 1.3 & 1.60 & 3.3 & 2.25 & 1.2 & 1.61 & 3.3 \\
\hline logASSET_THRESH & -0.02 & 0.2 & 0.12 & 1.7 & 0.05 & 0.4 & 0.10 & 1.5 \\
\hline \multicolumn{9}{|l|}{ Labor Market Policy Tools } \\
\hline logINCOME_2ndQUINTILE & 2.53 & 1.8 & -0.83 & 0.9 & 3.19 & 1.6 & -0.84 & 1.0 \\
\hline logEI_INDEX & 3.07 & 1.9 & 2.28 & 4.5 & 3.76 & 2.4 & 2.30 & 4.6 \\
\hline \multicolumn{9}{|l|}{ Macroeconomic Factors } \\
\hline UNEMPLOYMENT & -0.06 & 0.6 & -0.01 & 0.2 & -0.05 & 0.5 & -0.02 & 0.1 \\
\hline UNEMPLOYMENT_\{t-1\} & 0.08 & 1.2 & 0.00 & 0.1 & 0.01 & 0.2 & 0.00 & 0.3 \\
\hline UNEMPLOYMENT_\{t-2\} & 0.11 & 1.3 & 0.01 & 0.2 & 0.18 & 2.0 & 0.01 & 2.1 \\
\hline REALGDPGROWTH & 0.00 & 0.1 & -0.02 & 1.9 & -0.02 & 0.8 & -0.02 & 2.7 \\
\hline REALGDPGROWTH_\{t-1\} & -0.05 & 2.1 & -0.03 & 2.6 & -0.03 & 1.4 & -0.03 & 3.0 \\
\hline REALGDPGROWTH_\{t-2\} & -0.06 & 2.3 & -0.03 & 2.9 & -0.07 & 2.4 & -0.03 & 0.0 \\
\hline \multicolumn{9}{|l|}{ New Reform Strategies (Coarse) } \\
\hline NEWREFORM & -0.51 & 2.1 & -0.74 & 2.6 & 0.30 & 1.2 & -0.61 & 3.2 \\
\hline NEWREFORM_\{t-1\} & & & & & -1.11 & 2.8 & -0.15 & 0.8 \\
\hline cum effect: NEWREFORM & & & & & -0.81 & $(p=0.0288)$ & -0.76 & $(p=0.0224)$ \\
\hline \multicolumn{9}{|l|}{ Demographics } \\
\hline SINGLEPARENTS & 0.09 & 1.6 & -0.03 & 0.8 & 0.12 & 2.1 & -0.03 & 1.0 \\
\hline MIGRATION & -0.27 & 1.7 & -0.13 & 1.7 & -0.43 & 2.3 & -0.13 & 1.8 \\
\hline DROPOUT & 0.03 & 0.6 & 0.04 & 2.0 & 0.03 & 0.8 & 0.04 & 2.0 \\
\hline NONPERM_RESIDENTS & 0.58 & 2.2 & 0.48 & 4.3 & 0.56 & 2.2 & 0.48 & 4.5 \\
\hline Constant & -12.51 & 0.3 & -9.24 & 0.9 & -57.94 & 2.3 & -8.98 & 0.9 \\
\hline Province Fixed Effects & Yes & & Yes & & Yes & & Yes & \\
\hline Year Fixed Effects & Yes & & Yes & & Yes & & Yes & \\
\hline
\end{tabular}


Variables

Dependent Variable

PARTICIPATION*

Standard Reform Tools

logBENEFITS_SINGLE_ONECHILD

logASSET_THRESH

Labor Market Policy Tools

logINCOME_2ndQUINTILE

logEI_INDEX**

Macroeconomic Factors

UNEMPLOYMENT

UNEMPLOYMENT_\{t-1\}

UNEMPLOYMENT_\{t-2\}

REALGDPGROWTH

REALGDPGROWTH _\{t-1\}

REALGDPGROWTH_\{t-2\}

\section{New Reform Strategies (Finely Coded) \\ WORKREQ_STRONG \\ WORKREQ_WEAK \\ DIVERSION_STRONG \\ DIVERSION_WEAK \\ TIMELIMITS \\ logEARNINGS_THRESH \\ EARNINGS_TAX} New Reform Strategies (Coarse)
NEWREFORM

Demographics

SINGLEPARENTS

MIGRATION***

DROPOUT $* * * *$

NONPERM_RESIDENTS
Description

Welfare participation rate $=100 \times$ number of welfare recipients $/$ number of people age 64 and under

natural log of real welfare benefit level for single parents with one child natural log of real asset exemption threshold

natural log of market income of individuals in the second lowest income quintile natural log of 1 plus the Employment Insurance Index:

income replacement rate $\times$ [ maximum duration of employment insurance eligibility / minimum work requirement ]

unemployment rate for males aged 25-54

unemployment rate for males aged 25-54, lagged one period

unemployment rate for males aged 25-54, lagged two periods real GDP growth rate

real GDP growth rate, lagged one period

real GDP growth rate, lagged two periods

Work requirements with strong sanctions for non-compliance Work requirements with weak sanctions for non-compliance

Strong diversion strategies

Weak diversion strategies

Time limits on welfare eligibility

log of the real earning exemption threshold

marginal tax rate applied to earnings above threshold

Any three new reform strategies (above) in place concurrently

expressed as a percentage of the non-elderly population

number of single parents

net interprovincial migration

high school drop out rate

number of non-permanent residents

* Data for welfare participation in 1987 and 1988 are not available on a provincial level. Data for these two years were interpolated using a linear combination of welfare participation in 1986 and 1989.

** The Employment Insurance (EI) Index takes the form or $\mathrm{rD} / \mathrm{M}$, where $\mathrm{r}$ is the income replacement rate, $\mathrm{M}$ is the minimum amount of weeks worked to gain EI eligibility, and D is the duration of EI benefit flows for the minimally eligible individual. These policy variables have changed over the periods 1986-1989, 1990-1993, and 1994-2009. Income replacement, r, is set federally, taking the value of 0.6, 0.57, and 0.55, respectively. The values of $\mathrm{D}$ and $\mathrm{M}$ are dependent on the region's (province's) unemployment rate.

*** MIGRATION refers to the net flow of migrants into the province as a proportion of the destination province's population on a 0 to 100 percentage point scale. Migrant status depends on being a resident in the province left behind, and not on Canadian citizenship.

Data for high school drop out rates in years prior to 1990 are not available on a provincial level. Data for years 1986-1989 were imputed by calculating a linear trend based on the years 1990 through 2005. Missing values were then fitted on this trend line, by backwards forecasting. 